\title{
Ecdysteroid Derivatives that Reverse P-Glycoprotein-Mediated Drug Resistance
}

\author{
Roberta Bortolozzi, ${ }^{*} \triangle$ Andrea Luraghi, $\triangle$ Elena Mattiuzzo, Alessandro Sacchetti, Alessandra Silvani, ${ }^{*}$ \\ and Giampietro Viola
}

Cite This: J. Nat. Prod. 2020, 83, 2434-2446

Read Online

ACCESS I

Wll Metrics \& More

Article Recommendations

Supporting Information

ABSTRACT: The expression of multidrug resistance P-glycoprotein (P-gp) by cancer cells represents one of the major drawbacks to successful cancer therapy. Accordingly, the development of drugs that inhibit the activity of this transporter remains a major challenge in cancer drug discovery. In this context, several new ecdysteroid derivatives have been synthesized and evaluated as P-gp inhibitors. Two of them (compounds 9 and 14) were able to resensitize $\mathrm{CEM}^{\mathrm{Vb} 1100}$ and $\mathrm{LoVo}^{\mathrm{Doxo}}$ resistant cell lines to vinblastine and doxorubicin, respectively. Indeed, both compounds 9 and 14 increased the cellular accumulation of rhodamine 123 in cells expressing P-gp and stimulated basal P-glycoprotein-ATPase activity at a $1 \mu \mathrm{M}$ concentration, demonstrating their interference with the transport of other substrates in a competitive mode.

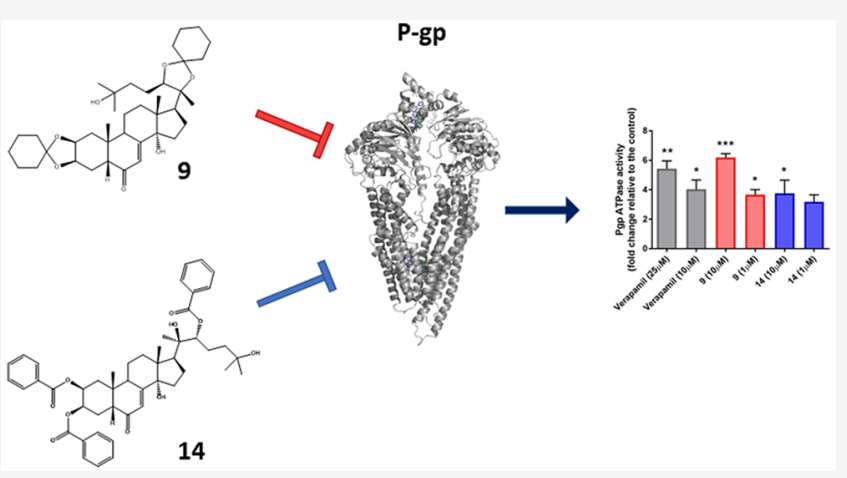
Moreover, in a medulloblastoma cell line (DAOY), compounds $\mathbf{9}$ and $\mathbf{1 4}$ reduced the side population representing cancer stem cells, which are characterized by a high expression of $A B C$ drug transporters. Further, in DAOY cells, the same two compounds synergized with cisplatin and vincristine, two drugs used commonly in the therapy of medulloblastoma. Molecular docking studies on the homology-modeled structure of the human P-glycoprotein provided a rationale for the biological results, validating the binding mode within the receptor site, in accordance with lipophilicity data and observed structure-activity relationship information. Altogether, the present results endorse these derivatives as promising P-gp inhibitors, and they may serve as candidates to reverse drug resistance in cancer cells.

$\mathrm{D}$ espite successful advances in cancer therapeutic strategies, multidrug resistance represents one of the primary causes of therapy failure. ${ }^{1}$ Biological membranes present a significant permeation barrier and thus play a critical role in the protection of pharmacokinetic compartments. Conversely, the activity of a drug ultimately depends on the ability of the compound to reach its target, as regulated by the basic physical characteristics of the drugs, as well as by their interactions with membrane transporters. A common mechanism shared by the majority of cancers is the overexpression of ATP-binding cassette $(\mathrm{ABC})$ efflux transporters, including P-glycoprotein (P-gp), multidrug resistance proteins (MRPs), and breast cancer resistance protein (BCRP). ${ }^{2} \mathrm{ABC}$ transporters are active components of biological membranes, but they act as a shield for drug-resistant cancer cells. Functional ABC transporters are large integral membrane proteins containing two transmembrane domains (TMDs) and two nucleotide-binding domains (NBDs). ${ }^{2,3}$ The molecular mechanism of transport is fueled by the energy of ATP hydrolysis, which results in a series of conformational changes, sweeping through the molecule from the cytoplasmic ATP-binding units to the TMD helices forming the transmembrane pore. ATP binding and hydrolysis regulate the association and disassociation of the NBD dimers, which is, in turn, coupled to a change in substrate binding affinity and transport. ${ }^{4}$ These membranous efflux pumps are able to extrude chemotherapeutics from cancer cells, preventing their uptake and the access to their cellular target. They promote the extrusion of structurally and functionally different chemotherapeutics, such as alkaloids, taxanes, topoisomerase inhibitors, and antimetabolites. The activity of $\mathrm{ABC}$ transporters has been associated with a poor prognosis, treatment failure, and reduced survival rate in many types of cancer, such as hematological malignancies, medulloblastoma, breast cancer, and pancreatic and colon carcinoma. ${ }^{5}$

Over the last few decades, one of the major challenges in cancer drug discovery has been the development of substances able to modulate/inhibit $\mathrm{ABC}$ efflux transporters. However, no compounds have been approved for cancer therapy, due to

Received: March 26, 2020

Published: August 13, 2020 
either their recurrent high intrinsic toxicity, pharmacokinetics interactions with anticancer drugs, with consequent increased toxicity of the anticancer drugs, or failure in demonstrating improvement in therapeutic efficacy. ${ }^{6}$

Medulloblastoma, the most frequent childhood primary malignant brain tumor, is generally treated with a combination therapy that includes etoposide, methotrexate, cisplatin, lomustine, cyclophosphamide, and vincristine. ${ }^{7}$ Recently, it has been demonstrated that the high frequency of recurrence and therapy failure in medulloblastoma is associated with a high expression of P-gp. This is crucial in children under three years that are treated with chemotherapy alone, to minimize the adverse effect of radiotherapy on the developing brain. ${ }^{8}$ In particular, $\mathrm{ABCB} 1$ is overexpressed in more than $40 \%$ of patient samples and is associated significantly with high risk and poor survival. Moreover, $\mathrm{ABC}$ transporters are highly expressed by the specialized endothelial cells that form the blood-brain barrier, and this constitutes a further obstacle to therapy success in brain tumors. In this context, strategies aimed at overcoming/inhibiting P-gp, thus enhancing the efficacy of chemotherapy, are still warranted.

Ecdysteroids represent a large family of steroid hormones, playing a crucial role in arthropod physiology. ${ }^{9}$ The most abundant representative of these compounds, 20-hydroxyecdysone, regulates the reproduction, embryogenesis, diapause, and molting of arthropods. Their role in plants is still to be fully understood, but it has been suggested that they have importance in several plants as defensive agents against nonadapted herbivores. An estimated $5-6 \%$ of terrestrial plant species accumulate detectable levels of ecdysteroids. ${ }^{10}$ Their common chemical skeleton retains the cholesteroloriginated side chain, contains typically $27-29$ carbon atoms, and is substituted with $4-8$ hydroxy groups. The A/B ring junction is usually cis, and a characteristic 7-en-6-one $(\alpha, \beta$ unsaturated ketone) functional group is present in ring $\mathrm{B}$.

Due to their significantly different structure as compared to vertebrate steroid hormones, ecdysteroids have no hormonal effects in humans. ${ }^{11}$ Rather, it has been shown that ecdysteroids are nontoxic in mammals. ${ }^{12}$ An oral $\mathrm{LD}_{50}$ value of higher than $6 \mathrm{~g} / \mathrm{kg}$ in mice and a wide range of beneficial health effects (including adaptogenic, anabolic, antihyperglycemic, hepatoprotective, immunoprotective, and wound healing) were described, ${ }^{9}$ which has encouraged the production and worldwide marketing of many food supplements, mainly containing 20-hydroxyecdysone.

Moving to medicinal chemistry studies, it has been demonstrated by Martins and co-workers ${ }^{13}$ that semisynthetic derivatives of ecdysteroids are able to inhibit the ABCB1 transporter and to revert resistance to doxorubicin in mammalian cancer cells expressing the human ABCB1 transporter. ${ }^{13,14}$ Their studies have identified lipophilicity as the key feature for the in vitro activity of the compounds, showing how the inactive natural compound 20-hydroxyecdysone may become a promising lead compound, after transformation to the corresponding diacetonide derivative.

Recently, an efficient multicomponent synthetic protocol has been developed by our group, starting from the easily available 20-hydroxyecdysone and allowing access to different kinds of peptide-ecdysteroid conjugates, which were evaluated for their ability to inhibit the ABCB1 pump. ${ }^{15}$ Progressing in this interest in ecdysteroids as potential multidrug resistance modulators, ${ }^{16}$ we aimed to investigate more deeply the role of the steroidal skeleton on bioactivity, also evaluating rarer and more expensive ecdysteroids. For this purpose, natural compounds $\mathbf{1 - 5}$ were selected by considering their structural diversification in terms of the number and position of the hydroxy groups present. In fact, this distinctive feature allows the design of a more varied library of functional derivatives, both esters and ketals, in order to go deeper into the role of lipophilicity and steric encumbrance, related to biological activity.

In the present study, the synthesis and structural characterization of new ecdysteroids derivatives are reported, as well as the evaluation of their ability to modulate P-gp-mediated drug efflux in multidrug resistant (MDR) cell lines. For the most active compounds, their ability to modulate Pgp-ATPase activity was also investigated, in an effort to assess their potential as new drug candidates to treat multi-drug-resistant cancers.

\section{RESULTS AND DISCUSSION}

Synthesis of Ecdysteroid Derivatives (6-28). Starting from ecdysteroids 1-5 (Figure 1) and exploiting different

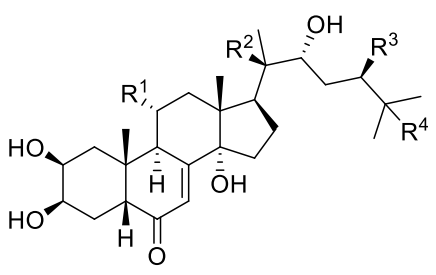

$\begin{array}{lcccc} & \mathrm{R}^{1} & \mathrm{R}^{2} & \mathrm{R}^{3} & \mathrm{R}^{4} \\ \text { 20-Hydroxyecdysone (1) } & \mathrm{H} & \mathrm{OH} & \mathrm{H} & \mathrm{OH} \\ \text { Ponasterone A (2) } & \mathrm{H} & \mathrm{OH} & \mathrm{H} & \mathrm{H} \\ \text { Ecdysone (3) } & \mathrm{H} & \mathrm{H} & \mathrm{H} & \mathrm{OH} \\ \text { Makisterone A (4) } & \mathrm{H} & \mathrm{OH} & \mathrm{CH}_{3} & \mathrm{OH} \\ \text { Ajugasterone C (5) } & \mathrm{OH} & \mathrm{OH} & \mathrm{H} & \mathrm{H}\end{array}$

Figure 1. Natural ecdysteroids used as starting materials.

chemical modifications of their hydroxy functional groups, two small families of derivatives, namely, 2,3-20,22 bis-ketals and various polyesters, were synthesized.

The 2,3-20,22 bis-ketals 6-9 were synthesized by adapting typical ketalization procedures (Scheme 1). Briefly, the reaction was carried out employing the appropriate ketone (acetone, cyclopentanone, or cyclohexanone) as solvent and camphosulfonic acid as catalyst and afforded the products in variable yields $(67-97 \%)$.

For the preparation of ester derivatives, two different protocols were considered. In the case of nonbulky esters, such as acetates and benzoates, standard conditions were applied. Employing the appropriate carboxylic acid anhydride or chloride in pyridine as solvent, the 2,3,22-triesters 10-15 were achieved in good yields. In such conditions, bulkier acylating agents (hexanoyl chloride and cinnamoyl chloride) gave exclusively the 2,22-diesters 16 and 17 in comparable yields (Scheme 2).

Aiming to investigate compounds at different degrees of lipophilicity, also the synthesis of tetra-ester derivatives was pursued. Preparation of tetraacetates 18-21 and tetrabenzoate 22 required modified reaction conditions, namely, the catalysis of $N, N^{\prime}$-dimethylaminopyridine/triethylamine in dichloromethane and longer reaction times (up to $96 \mathrm{~h}$ ) (Scheme 3). Under these conditions, 2,3,22-triester derivatives incorporating bulky acidic residues were obtained, such as 20 - 
Scheme 1. Synthesis of Ecdysteroid 2,3-20,22 Bis-Ketals $(6-9)^{a}$

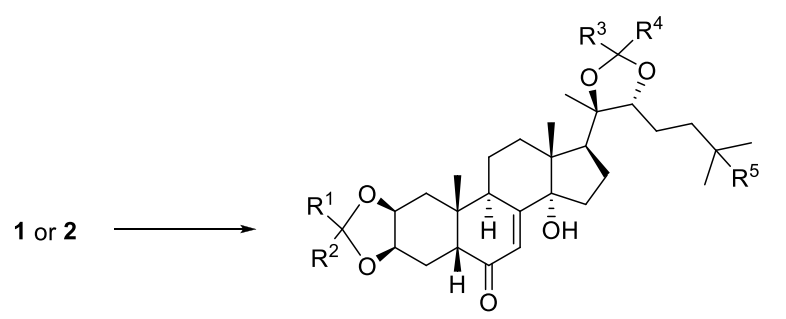

$$
\begin{array}{lccccc} 
& \mathrm{R}^{1} & \mathrm{R}^{2} & \mathrm{R}^{3} & \mathrm{R}^{4} & \mathrm{R}^{5} \\
\mathbf{6} & \mathrm{CH}_{3} & \mathrm{CH}_{3} & \mathrm{CH}_{3} & \mathrm{CH}_{3} & \mathrm{OH} \\
\mathbf{7} & \mathrm{CH}_{3} & \mathrm{CH}_{3} & \mathrm{CH}_{3} & \mathrm{CH}_{3} & \mathrm{H} \\
\mathbf{8} & -\mathrm{CH}_{2}\left(\mathrm{CH}_{2}\right)_{2} \mathrm{CH}_{2^{-}} & -\mathrm{CH}_{2}\left(\mathrm{CH}_{2}\right)_{2} \mathrm{CH}_{2^{-}} & \mathrm{OH} \\
\mathbf{9} & -\mathrm{CH}_{2}\left(\mathrm{CH}_{2}\right)_{3} \mathrm{CH}_{2^{-}} & -\mathrm{CH}_{2}\left(\mathrm{CH}_{2}\right)_{3} \mathrm{CH}_{2^{-}} & \mathrm{OH}
\end{array}
$$

${ }^{a}$ Reagents. General procedure A: camphosulfonic acid (0.01 mmol), 1 or $2(0.1 \mathrm{mmol})$, appropriate anhydrous ketone $(1.6 \mathrm{~mL}), 25^{\circ} \mathrm{C}, 24-$ $72 \mathrm{~h}$.

Scheme 2. Synthesis of Ecdysteroid Esters $(10-17)^{a}$
$1-4$

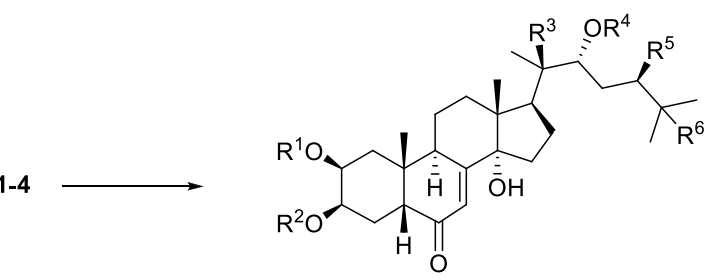

${ }^{a}$ Reagents. General Procedure B: 1-4 $(0.1 \mathrm{mmol})$, appropriate carboxylic acid anhydride or chloride $(0.5 \mathrm{mmol})$, pyridine $(2.5 \mathrm{~mL})$, $0{ }^{\circ} \mathrm{C}, 8-24 \mathrm{~h}$.

hydroxyecdysone trihexanoate (23) and trilaurate (24), ponasterone A trilaurate (25), and 20-hydroxyecdysone tricinnamate (26) and trioleate (27), all in acceptable yields.

Finally, reacting 20-hydroxyecdysone (1) with indolyl-3acetic acid anhydride (generated in situ by treatment of indolyl-3-acetic acid with dicyclohexylcarbodiimide (DCC) in anhydrous dioxane), the 2,3,22-tris (2-(1H-indol-3-yl) acetate derivative $\mathbf{2 8}$ was obtained in $83 \%$ yield (Scheme 4 ).

Compounds 9 and 14 Induce Significant Accumulation of Rhodamine 123 in CEM ${ }^{\text {Vbl100 }}$ and Lovo ${ }^{\text {Doxo }}$ ABCB1 Overexpressing Cell Lines. To assess the capability of the novel synthesized ecdysteroids to modulate the ABCB1 multidrug resistance pump, the $\mathrm{CEM}^{\mathrm{Vbl100}}$ and $\mathrm{LoVo}^{\text {Doxo }}$ cell lines were exposed to rhodamine 123 (Rho123), a fluorescent compound known as a good substrate of P-gp. ${ }^{17}$ The mean fluorescence intensity (MFI) was evaluated by flow cytometry. Compounds 24, 25, and 27 were not evaluated due to their very low solubility in aqueous media.

Cells were treated for $2 \mathrm{~h}$ with compounds at the concentration of $10 \mu \mathrm{M}$ and with verapamil at 25 and 10
Scheme 3. Synthesis of Ecdysteroid Esters $(18-27)^{a}$

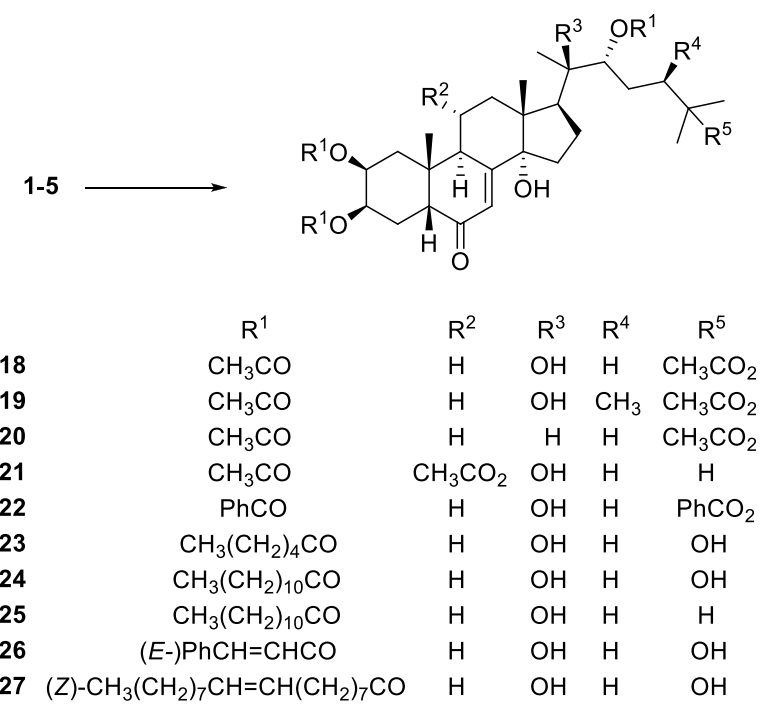

${ }^{a}$ Reagents. General Procedure C: 1-5 (0.1 mmol), $N, N^{\prime}$ dimethylaminopyridine $(0.4 \mathrm{mmol})$, triethylamine $(0.4 \mathrm{mmol})$, appropriate carboxylic acid chloride $(0.44 \mathrm{mmol}), \mathrm{CH}_{2} \mathrm{Cl}_{2}(2.5$ $\mathrm{mL}), 0{ }^{\circ} \mathrm{C}, 1-4$ days.

Scheme 4. Synthesis of 20-Hydroxyecdysone-2,3,22-tri(2(1H-indol-3-yl) Acetate (28)

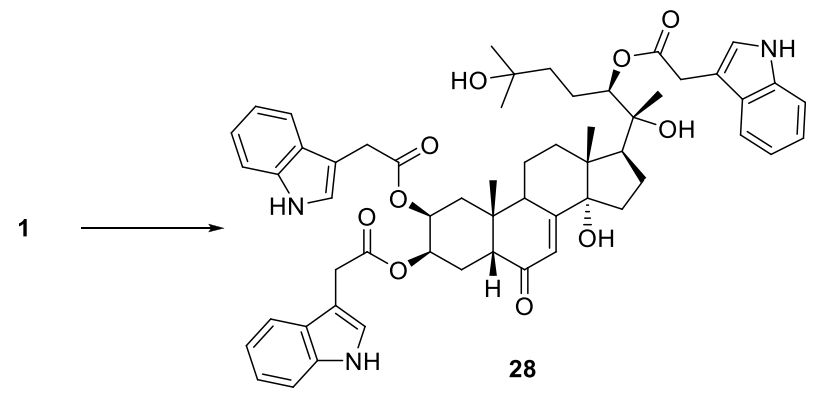

${ }^{a}$ Reagents. 2 -( $1 H$-indol-3-yl $)$ acetic acid $(0.7 \mathrm{mmol})$, DCC (0.7 $\mathrm{mmol})$, dry dioxane $(3 \mathrm{~mL}), 1 \mathrm{~h}$; then urea was filtered off and the filtrate added to 1 ( $0.1 \mathrm{mmol}), N, N^{\prime}$-dimethylaminopyridine $(0.05$ $\mathrm{mmol})$, dry dioxane $(3 \mathrm{~mL}), 40{ }^{\circ} \mathrm{C}, 22 \mathrm{~h}$.

$\mu \mathrm{M}$, as a positive control. As depicted in Figure 2, compounds 9 and 14, in CEM ${ }^{\mathrm{Vbl} 100}$ cells, prevented the efflux of Rho123 more than verapamil (fold change of MFI relative to the control of $5.2 \pm 1.2$ and $8.0 \pm 1.5$ vs $1.6 \pm 0.12$ ). Similar results, although less pronounced, were obtained in LoVo ${ }^{\text {Doxo }}$ cells.

The data obtained indicated compounds $\mathbf{9}$ and $\mathbf{1 4}$ as the most promising ones and suggest that a possible structureactivity relationship (SAR) can be proposed considering the lipophilic profile of these examined compounds. Both active compounds 9 and $\mathbf{1 4}$ are derivatives of $20-\mathrm{OH}$ ecdysone $\mathbf{1}$. Among bis-ketals, compound $\mathbf{9}$ is the most lipophilic, due to the presence of two spiro-cyclohexane rings. On only slightly reducing the spiro-ring size, such as in the corresponding spirocyclopentane derivative $\mathbf{8}$, the activity dramatically decreased, as well as in the acetone ketal derivatives 6 and 7 . Moving to ester derivatives, the tribenzoic ester 14 displayed the highest activity among all compounds tested.

Since it was known $^{13}$ that less polar ecdysteroids are endowed with a better activity profile in comparison to those 

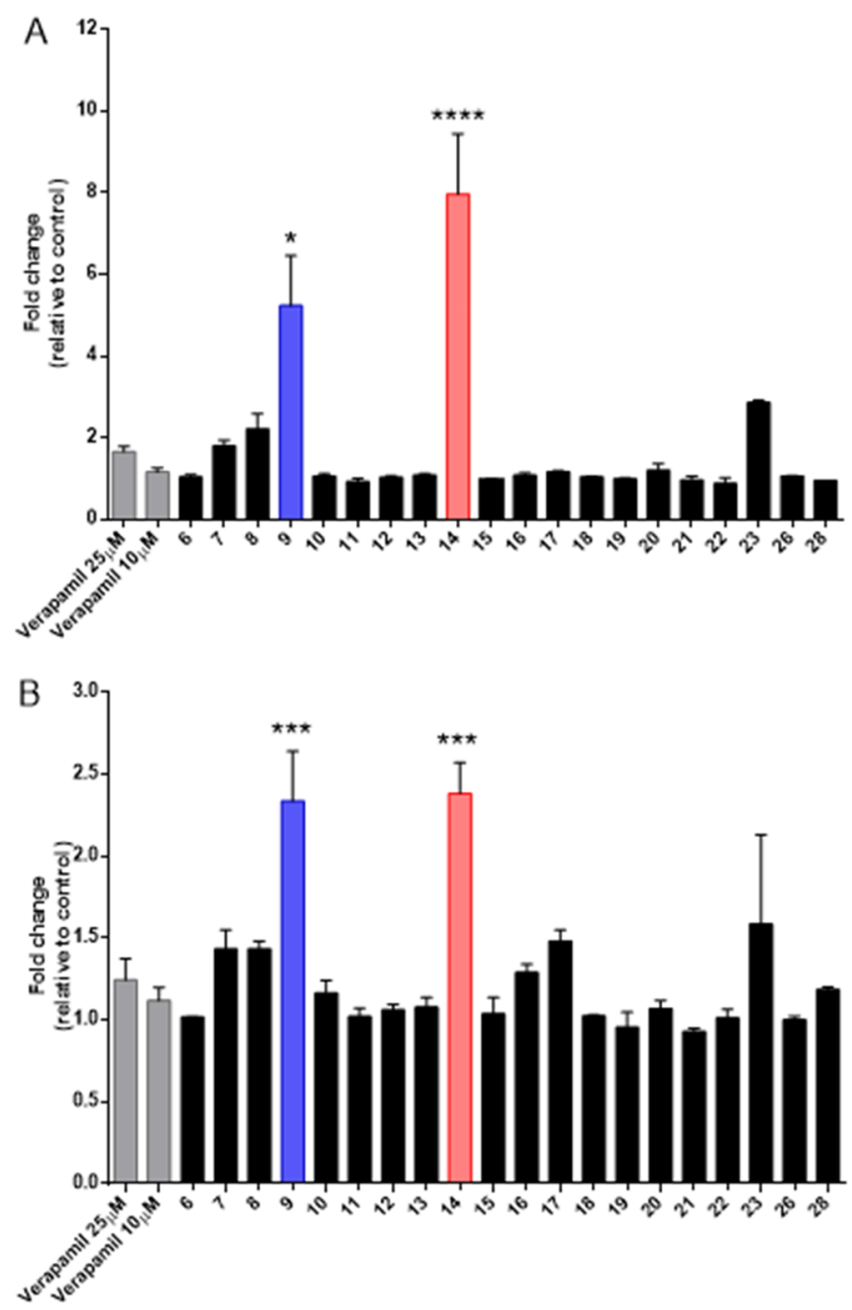

Figure 2. Quantification presented by fold change in Rho123 fluorescence after a $2 \mathrm{~h}$ treatment of CEM ${ }^{\mathrm{Vbl} 100}$ cells (panel A) and $\mathrm{LoVo}^{\text {Doxo }}$ cells (panel B), compared to untreated cells. Each compound was used at a concentration of $10 \mu \mathrm{M}$. Verapamil was used at concentrations of 25 and $10 \mu \mathrm{M}$. Data are represented as means \pm SEM of three independent experiments. Statistical significance was determined using ANOVA with Newman-Keuls or Bonferroni correction. Asterisks indicate a significant difference between the new compounds and verapamil at $25 \mu \mathrm{M}$. ${ }^{*} p<0.05$, $* * p<0.01, * * * p<0.001, * * * * p<0.0001$.

of higher polarity, the $\operatorname{cLogP}$ was calculated for all new derivatives (Table 1). The two most active compounds, 9 and 14, have $\operatorname{cLog} P$ values of 5.75 and 6.65 , respectively, representing the optimal range for activity. As was observed, all other compounds have higher or lower cLogP values, with the only exceptions being derivatives 7 (cLogP 6.06) and 28 (cLogP 6.27). However, for these two compounds, some

Table 1. Lipophilic Profile of Ecdysteroid Derivatives 6-28

$\begin{array}{cccccc}\text { compound } & \text { cLogP } & \text { compound } & \text { cLogP } & \text { compound } & \text { cLogP } \\ \mathbf{6} & 3.85 & \mathbf{1 3} & 2.85 & \mathbf{2 0} & 3.79 \\ \mathbf{7} & 6.06 & \mathbf{1 4} & 6.65 & \mathbf{2 1} & 2.50 \\ \mathbf{8} & 4.12 & \mathbf{1 5} & 8.85 & \mathbf{2 2} & 9.51 \\ \mathbf{9} & 5.75 & \mathbf{1 6} & 5.31 & \mathbf{2 3} & 7.79 \\ \mathbf{1 0} & 1.44 & \mathbf{1 7} & 4.86 & \mathbf{2 6} & 7.90 \\ \mathbf{1 1} & 3.65 & \mathbf{1 8} & 2.39 & \mathbf{2 8} & 6.27 \\ \mathbf{1 2} & 1.84 & \mathbf{1 9} & 2.78 & & \end{array}$

considerations on their specific structural features can be made. Compound 7 is characterized by a penalizing low lipophilicity in the region of ring $A$, due to the presence of the acetone ketal. If compared with its analogue $6(\operatorname{cog} P \quad 3.85)$, the increased $\operatorname{cLog} \mathrm{P}$ of 7 is only due to the lack of the $\mathrm{OH}-25$ group. However, from previous SAR studies, the role of this portion of the molecule seems not to be crucial for receptor interaction and activity. ${ }^{14}$ In the case of compound 28 , the optimal value of cLogP is likely counteracted by the presence of the bulky indolyl-3-acetic residues, which hinders the correct interaction with the small $\mathrm{M}$-site located on the transmembrane domain of the P-gp (see below for molecular modeling discussion). ${ }^{18}$

When cLogP becomes too high, other phenomena related to poor pharmacodynamics can lead to a low activity. This is the case of inactive compound $\mathbf{1 5}$, which is quite similar to active 14, but shows a cLogP of 8.85 , due to the lack of the $\mathrm{OH}-25$ group.

Given the great difference in activity of compounds $\mathbf{9}$ and $\mathbf{1 4}$ compared to all the other test compounds, a subsequent more in-depth assessment of the biological profile, including the Pgp inhibitory behavior, was carried out only on these two derivatives.

Effect of Compounds 9 and 14 on ABCB1-Mediated Resistance to Vinblastine and Doxorubicin in ABCB1Overexpressing Drug-Selected Cell Lines. Compounds 9 and 14 were investigated further for their ability to enhance the activity of vinblastine in the $\mathrm{CEM}^{\mathrm{Vbl} 100}$ cell line and of doxorubicin in the LoVo ${ }^{\text {Doxo }}$ cell line. Cells were treated with vinblastine in combination with 9 and $\mathbf{1 4}$ at a fixed concentration ratio (1:10), and cell viability was analyzed by an MTT assay after $48 \mathrm{~h}$. As depicted in Figure 3, both compounds induced a significant increase in the cytotoxicity of vinblastine in a synergistic way, as demonstrated by combination indexes $(\mathrm{CI})<1$, as calculated according to Chou et al. ${ }^{19,20}$

Moreover, compounds $\mathbf{9}$ and $\mathbf{1 4}$ were also able to increase the cytotoxicity of doxorubicin in $\mathrm{ABCB} 1$-overexpressing LoVo ${ }^{\text {Doxo }}$ cells. Also in this case, combination indexes calculated after $48 \mathrm{~h}$ of treatment indicated a synergistic effect between doxorubicin and compound 9 or 14 .

Effects of Compounds 9 and 14 in Human Peripheral Blood Lymphocytes. Aiming to obtain a preliminary indication of their cytotoxic potential in normal human cells, new ecdysteroids derivatives $\mathbf{9}$ and $\mathbf{1 4}$ were evaluated in vitro against peripheral blood lymphocytes (PBLs) from healthy donors. As depicted in Table 2, compound 9 showed a low toxicity both in quiescent and in proliferating lymphocytes in the presence of the mitogenic stimulus phytohematoaglutinin (PHA), having a $\mathrm{GI}_{50}$ of 61.7 and $42.8 \mu \mathrm{M}$, respectively. On the other hand, compound $\mathbf{1 4}$ was practically devoid of activity in quiescent lymphocytes, while it showed a weak cytotoxic activity in proliferating lymphocytes.

Effect of Compounds 9 and 14 on the Basal ATPase Activity of P-gp. To clarify further the mode of action of compounds 9 and 14, their effect on basal P-glycoproteinATPase activity was evaluated on recombinant human P-gp in a cell membrane fraction. Verapamil, a competitive inhibitor of P-gp activity that stimulates ATPase activity, was used as a positive control. At concentrations of 1 and $10 \mu \mathrm{M}$, compounds 9 and 14 stimulated basal P-glycoprotein-ATPase activity by 6 -fold and by 4-fold, respectively, whereas verapamil, at 25 and $10 \mu \mathrm{M}$ concentrations, stimulated the 

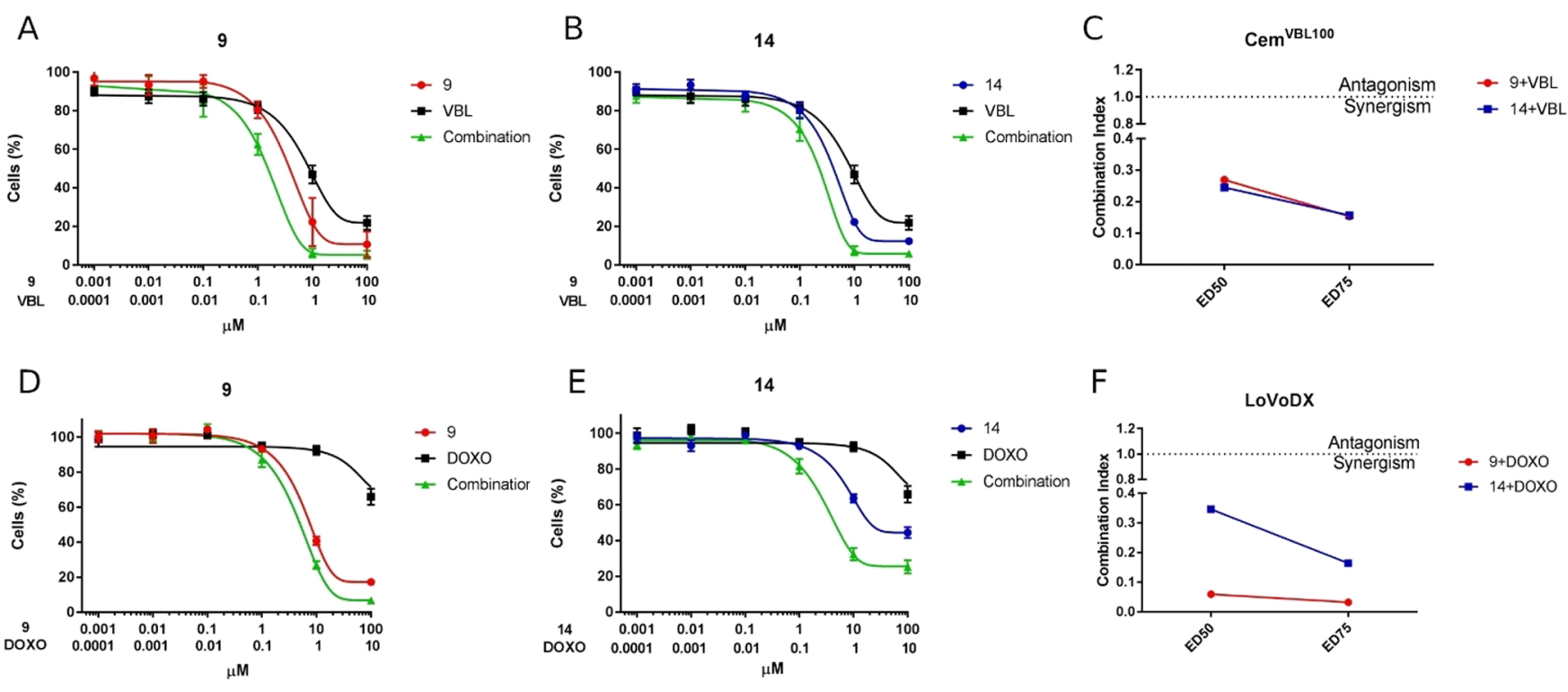

F

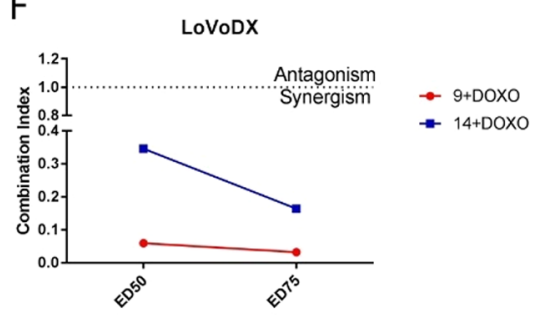

Figure 3. Effect of compounds $\mathbf{9}$ and $\mathbf{1 4}$ alone and in combination with vinblastine in $\mathrm{CEM}^{\mathrm{Vbl} 100}$ (panels A and B) and doxorubicin in LoVo Doxo (panels D and E) cells. Cells were treated at the indicated concentrations and fixed combination ratios, and viability was assessed by the MTT test after $48 \mathrm{~h}$ of incubation. Data are expressed as means \pm SEM of three independent experiments. Combination indexes (CI) are calculated at the $\mathrm{ED}_{50}$ and $\mathrm{ED}_{75}$ for vinblastine (panel C) and doxorubicin (panel F) combination, where synergism is defined by $\mathrm{CI}<1$.

Table 2. Cytotoxicity of 9 and 14 in Human Peripheral Blood Lymphocytes (PBLs)

\begin{tabular}{cll} 
& \multicolumn{2}{c}{$\mathrm{GI}_{50}(\mu \mathrm{M})^{a}$} \\
\cline { 2 - 3 } compound & PBLs $_{\text {resting }}{ }^{a}$ & PBLs $_{\mathrm{PHA}^{c}}$ \\
$\mathbf{9}$ & $61.7 \pm 9.6$ & $42.8 \pm 16.1$ \\
$\mathbf{1 4}$ & $>100$ & $19.9 \pm 6.7$
\end{tabular}

${ }^{a}$ Compound concentration required to inhibit cell growth by $50 \%$. ${ }^{b}$ PBLs not stimulated with PHA. ${ }^{c}$ PBLs stimulated with PHA.

ATPase activity by about 6- and 4-fold, respectively (Figure 4, panel A). These data demonstrate that compounds 9 and 14 are potent stimulators of ATPase activity of P-gp, and thus, in the same manner of verapamil, both compounds interfere with P-gp transport activity, in a competitive way with another substrate, as described above.

Compounds 9 and 14 Decrease P-Glycoprotein Expression in the Multi-Drug-Resistant CEM ${ }^{\text {Vbl100 }}$ Cell Line. Muller and co-workers ${ }^{21}$ demonstrated previously that another approach to reverse multidrug resistance can be the modulation of transcriptional regulation of $\mathrm{ABCB} 1$ by pharmacological agents. In particular, they determined that verapamil treatment induces a decrease in the mRNA expression level of the mdrl gene, through a transcriptional or post-transcriptional mechanism. In this context, the effects of compounds 9 and $\mathbf{1 4}$ on the mdrl/P-gp expression level were measured on the $\mathrm{CEM}^{\mathrm{Vb} 100}$ cell line, by real-time reverse transcriptase polymerase chain reaction (RT-PCR). As shown in Figure 4 (panel B), a significant decrease in mdr1 mRNA expression was observed after $24 \mathrm{~h}$ of treatment, with 9 or 14 at a concentration of $10 \mu \mathrm{M}$. Treatment with $25 \mu \mathrm{M}$ verapamil was performed as a positive control.

Compounds 9 and 14 Reduce the Side Population Subset and Sensitize the Medulloblastoma DAOY Cell Line to Vincristine and Cisplatin. A particular characteristic of stem cells is the high expression level of specific $A B C$ drug transporters. ${ }^{22}$ Like normal stem cells, also a subpopulation of cancer stem cells, known as "side population" (SP) cells, highly

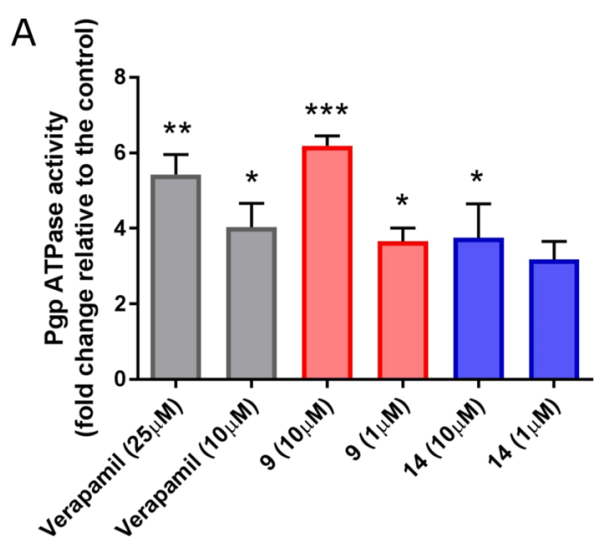

B

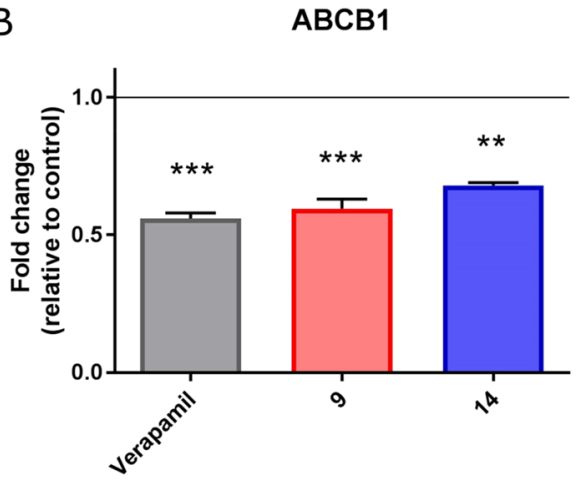

Figure 4. (A) Effects of compounds $\mathbf{9}$ and $\mathbf{1 4}$ on the ATPase activity of human P-gp. Each compound was tested at the concentrations of 1 and $10 \mu \mathrm{M}$, and verapamil at concentrations of 10 and $25 \mu \mathrm{M}$. The Pgp ATPase activity was expressed as fold changes, compared to untreated controls. (B) RT-PCR analysis of P-gp expression level on the $\mathrm{CEM}^{\mathrm{Vbl100}}$ cell line, after exposure of compounds $\mathbf{9}$ and $\mathbf{1 4}$ at a concentration of $10 \mu \mathrm{M}$ for $24 \mathrm{~h}$. Verapamil was used at a concentration of $25 \mu \mathrm{M}$. Data are expressed as means \pm SEM of three independent experiments. ${ }^{*} p<0.05 ;{ }^{*} p<0.01$; ${ }^{* *} p<0.001$. 

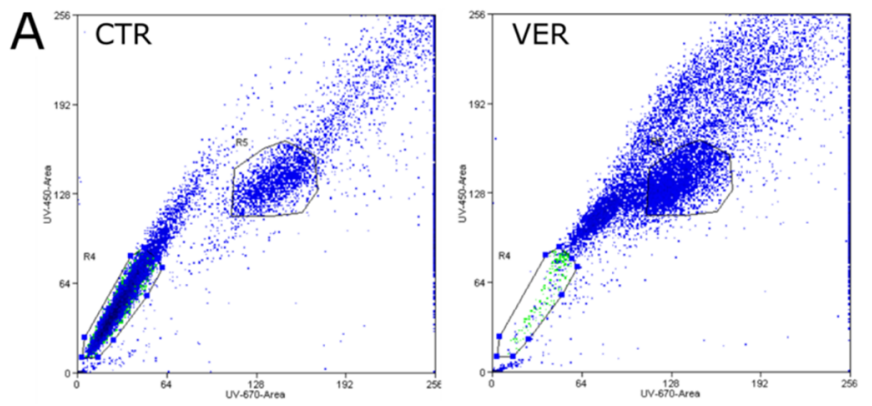

B
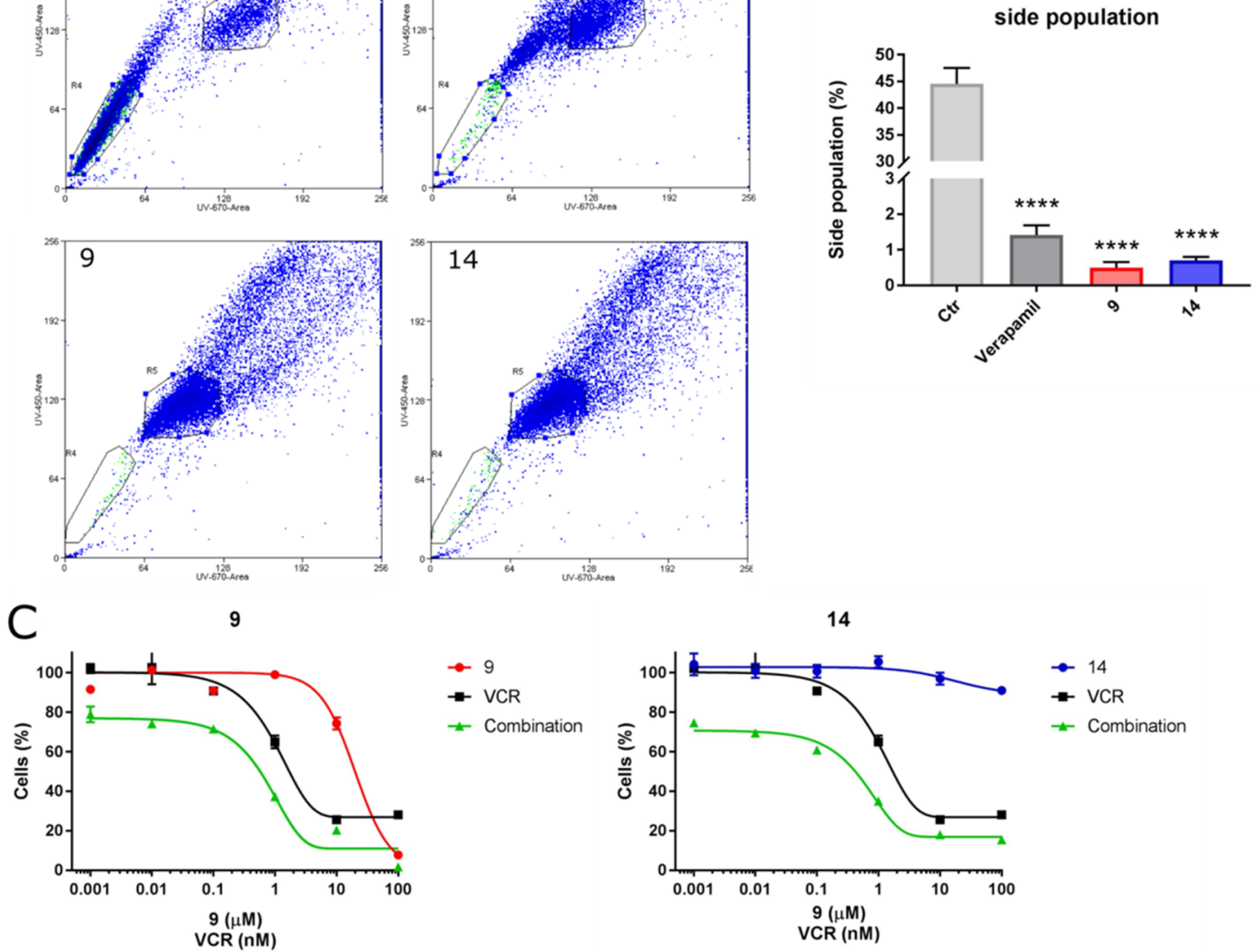

D

9
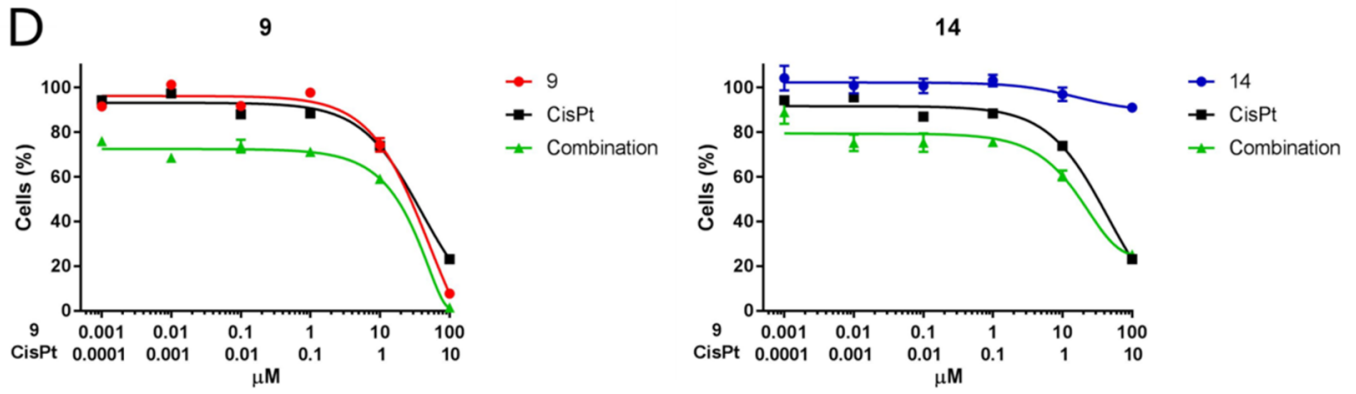

$\mathrm{E}$

Combination Index (ED50)

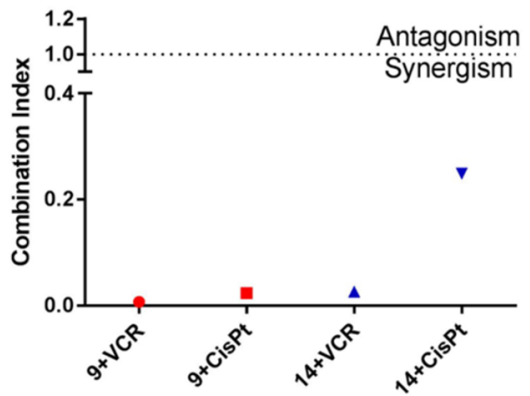

Figure 5. (A) Flow cytometric analysis of SP cells in a medulloblastoma cell line (DAOY). Representative histograms obtained after $2 \mathrm{~h}$ of treatment with compounds 9 and $\mathbf{1 4}$ at a concentration of $10 \mu \mathrm{M}$. Verapamil $(25 \mu \mathrm{M})$ was used as a positive control. (B) Quantification of SP cells under the conditions described in panel A. Data are expressed as means \pm SEM. ****p 0.0001 vs ctr. (C) MTT cell viability assay in the DAOY cell line treated with compounds $\mathbf{9}$ and $\mathbf{1 4}$ in combination with vincristine (VCR) or cisplatin (cisPt) for $72 \mathrm{~h}$. The percentages of cell viability were normalized to untreated cells. Data are represented as the means \pm SEM of at least three independent experiments. (E) The combination index (CI) calculated at the $\mathrm{ED}_{50}$ for VCR with the cisplatin synergism is defined by $\mathrm{CI}<1$. 
Table 3. Results from Docking Studies on the Human P-Glycoprotein Model Receptor

\begin{tabular}{|c|c|c|c|c|c|c|c|c|}
\hline & \multicolumn{4}{|c|}{ transmembrane domain (TMD) } & \multicolumn{4}{|c|}{ nucleotide binding domain (NMD) } \\
\hline & $\begin{array}{l}\text { no. of } \\
\text { clusters }\end{array}$ & $\begin{array}{l}\text { lowest } \\
\text { bind. } E^{a}\end{array}$ & lowest bind. $E^{b}$ & $\begin{array}{l}\text { binding energy of the first most } \\
\text { populated cluster }\end{array}$ & $\begin{array}{l}\text { no. of } \\
\text { clusters }\end{array}$ & $\begin{array}{l}\text { lowest } \\
\text { bind. } E^{a}\end{array}$ & lowest bind. $E^{b}$ & $\begin{array}{l}\text { binding energy of the first most } \\
\text { populated cluster }\end{array}$ \\
\hline 9 & 20 & -13.15 & $-11.94 \pm 0.81$ & $-11.94 \pm 0.81$ & 18 & -10.26 & $-9.13 \pm 0.73$ & $-9.02 \pm 0.67$ \\
\hline 14 & 43 & -13.30 & $-13.30 \pm 0.00$ & $-9.10 \pm 0.96$ & 54 & -8.66 & $-7.69 \pm 0.00$ & $-6.33 \pm 0.48$ \\
\hline
\end{tabular}

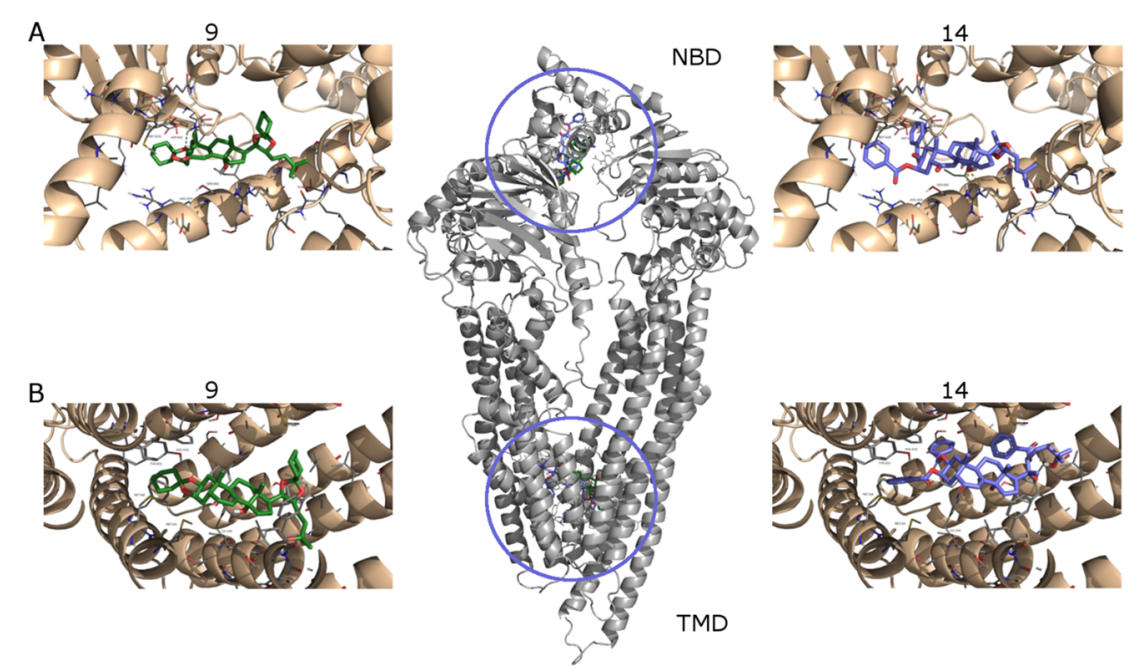

Figure 6. Binding modes for compound 9 (left, green color) and 14 (right, blue color) in the NMD (A, upper) and TMD (B, lower) domains, as obtained from docking simulations.

express $\mathrm{ABC}$ transporters and may be analyzed by flow cytometry, owing to their ability to extrude Hoechst 33342 dye. $^{23} \mathrm{SP}$ cells are pluripotent and show resistance to many cytotoxic drugs, unlike non-SP cells. ${ }^{24}$ SP cells have been identified successfully in a wide range of solid tumors, including breast, lung, prostate, ovarian, glioma, and pancreatic cancers $^{25-30}$ and have been described as playing a critical role in tumor initiation, maintenance, progression, and relapse. ${ }^{31}$

To evaluate the ability of $\mathbf{9}$ and $\mathbf{1 4}$ to target SP cells by inhibition of an ABCB1 transporter, medulloblastoma DAOY cells were treated with 9,14 , or verapamil for $2 \mathrm{~h}$, and the capacity of cells to extrude Hoechst dye was measured by flow cytometry. Compounds $\mathbf{9}$ and $\mathbf{1 4}$ were able to inhibit the $\mathrm{ABCB} 1$ transporter reducing $\mathrm{SP}$ population, as shown in Figure 5 (panels $\mathrm{A}$ and $\mathrm{B}$ ).

In order to assess if ecdysteroid derivatives 9 and 14 could enhance the efficacy of drugs commonly used in medulloblastoma therapy protocols, DAOY cells were treated with cisplatin or vincristine in the presence or absence of 14 or 9 , at a fixed molar combination. As depicted in Figure 5 (panels CE), both compounds synergized with the chemotherapy used, as confirmed by the low CI value, as calculated by Chou's method. ${ }^{19,20}$ Such results therefore show that the pharmacological inhibition of the P-gp activity, carried out by 9 and 14, significantly increases the cell death effects induced by the treatment with the conventional chemotherapeutic agents.

Molecular Modeling. In order to elucidate the possible interaction of the active ecdysteroid derivatives with the receptor, a docking study was performed, using a homologymodeled structure of the human P-glycoprotein. This receptor has been recognized to have two main binding sites, the cytosolic nucleotide-binding domain and the transmembrane domain, formed by six helices. ${ }^{32,33}$ In the latter, three different sites have been described according to the drug bonded, namely, the R-site, the $\mathrm{M}$-site, and the $\mathrm{H}$-site. ${ }^{18}$ The $\mathrm{M}$-site site has the smallest volume if compared with the other two sites. Docking calculations were run for the two most promising molecules, 9 and 14, and both the NMD and TMD binding sites were explored. The resulting conformations were clustered according to a heavy atom RMSD $<5 \AA$. Besides taking into account the lowest energy pose, for each cluster the energy spread (average and standard deviation) was also evaluated. The results are reported in Table 3. For both compounds, the lowest binding energies were obtained from the interaction with the TMD site. The lower number of clusters found for 9 could be ascribed to the lower flexibility of such a derivative, likely due to the presence of two spirocyclohexane rings. The lowest energy poses have similar energy values $(-13.15$ and $-13.30 \mathrm{kcal} / \mathrm{mol}$, for 9 and $\mathbf{1 4}$, respectively). Cluster analysis apparently indicates a preference for 14 ( 1 member in the lowest energy cluster; $-13.30 \pm 0.00$ $\mathrm{kcal} / \mathrm{mol}$ ) over 9 (32 members in the lowest energy cluster; $-11.94 \pm 0.81 \mathrm{kcal} / \mathrm{mol})$. Thus, if the binding energy of the first most populated cluster is considered, $9(-11.94 \pm 0.81$ $\mathrm{kcal} / \mathrm{mol}$ ) showed a more favorable interaction with the receptor than $14(-9.10 \pm 0.96 \mathrm{kcal} / \mathrm{mol})$. Similar considerations were made for the NBD site, where again 9 displayed the lowest binding energy. In summary, from this analysis, it appears that compounds 9 and $\mathbf{1 4}$ preferentially bind at the TMD site of the P-glycoprotein with almost equal efficiency, in accordance with biological data.

Within the TMD binding site, the ligands are in contact with the side-chain residues as a result of hydrophobic and $\pi-\pi$ interactions. A detailed analysis of the main interacting residues (Met 68, Met 67, Phe 336, Ile340, Tyr 953, Phe 978, Met 986) established that the ligands are located 
preferentially in the M-site of the receptor. These findings are in agreement with a previously reported study on the action of cardiotonic steroids as P-glycoprotein inhibitors. ${ }^{34}$

In summary, starting from natural ecdysteroids $\mathbf{1 - 5}$ and exploiting the reactivity of their hydroxy functional groups, a series of derivatives was synthesized with the aim of modulating their P-gp inhibitory activity. From the Rh123 assay, compounds $\mathbf{9}$ and $\mathbf{1 4}$ were identified, among the series, as the most promising compounds as potential P-gp inhibitors. Such derivatives are endowed with very low toxicity, as demonstrated by the high values of $\mathrm{GI}_{50}$ evaluated in human PBL. Concerning the capacity to reverse P-gp activity in $\mathrm{CEM}^{\mathrm{Vbl100}}$ cells, compounds $\mathbf{9}$ and $\mathbf{1 4}$ at a concentration of 10 $\mu \mathrm{M}$ were approximately 4 - and 7 - fold, respectively, more potent than verapamil used at the same concentration. Less pronounced, but still significant, is the effect of $\mathbf{9}$ and $\mathbf{1 4}$ in LoVo ${ }^{\text {Doxo }}$ cells, another P-gp-overexpressing cell line, where both compounds ware observed as 1.5 -fold more potent than verapamil.

From a mechanistic point of view, both compounds 9 and 14 induce P-gp ATPase activity, suggesting that they behave as substrates for transport, thereby inhibiting P-gp activity by competition with other substrates. Interestingly, derivatives 9 and $\mathbf{1 4}$ are able to reduce significantly the percentage of the side population in the medulloblastoma cell line DAOY. As it is well known, the side population represents that fraction of cells, also known as cancer stem cells or tumor-initiating cells, that are characterized by the presence of a high level of drugefflux pumps. In this context, the fact that these two new compounds are capable of inducing a synergistic effect when combined with cisplatin or vincristine, two drugs used in the treatment of medulloblastoma, is particularly relevant.

In the present work, it was found also that the preferred binding site for the most active compounds within the P-gp is the M-site, in agreement with the literature for the binding of steroids on P-gp. ${ }^{18}$ Due to an increased presence of aromatic residues (Phe and Tyr), the M-site provides a more hydrophobic environment, compared to the $\mathrm{H}$-site and the R-site. From docking experiments, it appears that the presence of highly lipophilic residues on the A ring is beneficial to activity, since this part of the molecule is buried in the most hydrophobic region of the M-site. Moreover, the presence of aromatic rings in this region of the ligand enhances the site interaction, through $\pi-\pi$ contacts with aromatic residues.

In conclusion, with compounds 9 and 14, the best possible arrangement of functional groups within the active binding site takes place, making these ecdysteroid derivatives the most promising candidates as P-gp inhibitors. Relying on a considerable amount of favorable biological data, they have the potential to be used in association with conventional chemotherapies in the treatment of cancers affected by P-gpmediated MDR.

\section{EXPERIMENTAL SECTION}

General Experimental Procedures. All solvents and reagents were purchased from commercial sources and used without further purification. All reactions were carried out under a dry nitrogen atmosphere and were monitored by thin-layer chromatography (TLC) on precoated silica gel $60 \mathrm{~F} 254$; spots were visualized with UV light or by treatment with a $1 \%$ aqueous $\mathrm{KMnO}_{4}$ solution. Optical rotations were determined on a JASCO P-1030 polarimeter using the sodium $\mathrm{D}$ line $(\lambda=589 \mathrm{~nm})$ at $20{ }^{\circ} \mathrm{C}$ in $\mathrm{MeOH} .{ }^{1} \mathrm{H}$ and ${ }^{13} \mathrm{C}$ NMR spectra were recorded in $\mathrm{CDCl}_{3}$ on a Bruker Advance 400 spectrometer (400 and $101 \mathrm{MHz}$ ) with TMS as internal standard.
Chemical shifts are reported in parts per million relative to the residual solvent. Multiplicities in ${ }^{1} \mathrm{H}$ NMR are reported as follows: $s=$ singlet, $\mathrm{d}=$ doublet, $\mathrm{t}=$ triplet, $\mathrm{m}=$ multiplet, $\mathrm{br}=$ broad. HRMS were measured in ESI mode on a Waters Q-Tof Micromass instrument equipped with a TOF mass analyzer. Products were purified by flash chromatography (FC) on Merck silica gel 60 (230-400 mesh).

General Procedure A for Ketalization of Ecdysteroids (GPA). Camphosulfonic acid $(2.3 \mathrm{mg}, 0.01 \mathrm{mmol})$ was added to a stirred suspension of the appropriate ecdysteroid $(0.1 \mathrm{mmol})$, in the appropriate anhydrous ketone $(1.6 \mathrm{~mL})$ under a nitrogen atmosphere. The reaction mixture was stirred at room temperature for $24-72 \mathrm{~h}$ until the conversion was found to be complete by TLC analysis and then diluted with ethyl acetate $(5 \mathrm{~mL})$ and quenched with a $5 \%$ aqueous solution of $\mathrm{NaHCO}_{3}(5 \mathrm{~mL})$. The organic phase was washed with saturated aqueous $\mathrm{NaCl}$, dried over anhydrous $\mathrm{Na}_{2} \mathrm{SO}_{4}$, filtered, and concentrated under reduced pressure to dryness. The resulting crude product was purified by $\mathrm{FC}$ on $\mathrm{SiO}_{2}$ as described below.

General Procedure B for Esterification of Ecdysteroids (GPB). To a stirred solution of the appropriate ecdysteroid $(0.1 \mathrm{mmol})$ in anhydrous pyridine $(2.5 \mathrm{~mL})$, under a nitrogen atmosphere at $0{ }^{\circ} \mathrm{C}$, was slowly added over $5 \mathrm{~min}$ the appropriate carboxylic acid anhydride or chloride $(0.5 \mathrm{mmol})$, and the resulting mixture was stirred at room temperature for $8-24 \mathrm{~h}$ until the conversion was found to be complete by TLC analysis. The resulting solution was dropped in $10 \mathrm{~mL}$ of $5 \%$ aqueous solution of $\mathrm{H}_{3} \mathrm{PO}_{4}$ and extracted twice with ethyl acetate $(2 \times 5 \mathrm{~mL})$. The combined organic layers were washed with a $5 \%$ aqueous solution of $\mathrm{NaHCO}_{3}(2 \times 5 \mathrm{~mL})$, dried over anhydrous $\mathrm{Na}_{2} \mathrm{SO}_{4}$, filtered, and concentrated under reduced pressure to dryness. The resulting crude product was purified by $\mathrm{FC}$ on $\mathrm{SiO}_{2}$, as described below.

General Procedure C for Esterification of Ecdysteroids (GPC). To a stirred solution of the appropriate ecdysteroid $(0.1 \mathrm{mmol})$, $N, N^{\prime}$-dimethylaminopyridine $(49.2 \mathrm{mg}, 0.4 \mathrm{mmol})$, and triethylamine $(56 \mu \mathrm{L}, 0.4 \mathrm{mmol})$, in anhydrous dichloromethane $(2.5 \mathrm{~mL})$ under a nitrogen atmosphere at $0{ }^{\circ} \mathrm{C}$, was slowly added the appropriate carboxylic acid chloride $(0.44 \mathrm{mmol})$ over a $5 \mathrm{~min}$ period. The resulting mixture was stirred at room temperature for 1-4 days, until the conversion was found to be complete by TLC analysis. The solution was dropped in $10 \mathrm{~mL}$ of a $5 \%$ aqueous $\mathrm{H}_{3} \mathrm{PO}_{4}$ solution and extracted twice with ethyl acetate $(2 \times 5 \mathrm{~mL})$. The combined organic layers were dried over anhydrous $\mathrm{Na}_{2} \mathrm{SO}_{4}$, filtered, and concentrated under reduced pressure to dryness. The resulting crude product was purified by $\mathrm{FC}$ on $\mathrm{SiO}_{2}$ as described below.

20-Hydroxyecdysone-2,3,20,22-diacetonide (6). This was prepared according to GP-A using 20-hydroxyecdysone (1) and acetone; FC: $n$-hexane-EtOAc, 1:1; yield: $53.2 \mathrm{mg}$, 97\%; white solid. Spectroscopic data were in accordance with the literature. ${ }^{13}$

Ponasterone-2,3,20,22-diacetonide (7). This was prepared according to GP-A using ponasterone A (2) and acetone; FC: $n$ hexane-EtOAc, $1.5: 1$; yield: $52.0 \mathrm{mg}$, 95\%; white solid. Spectroscopic data are in accordance with the literature. ${ }^{13}$

20-Hydroxyecdysone-2,3,20,22-dicyclopentyl-ketal (8). This was prepared according to GP-A using 20-hydroxyecdysone (1) and cyclopentanone; FC: $n$-hexane-EtOAc, $1: 1$; yield: $41.0 \mathrm{mg}, 67 \%$; white solid; mp $108.3-109.5^{\circ} \mathrm{C}$; $[\alpha]_{\mathrm{D}}^{20}+44.8(c 0.98, \mathrm{MeOH}) ;{ }^{1} \mathrm{H}$ NMR $\left(400 \mathrm{MHz}, \mathrm{CDCl}_{3}\right) \delta 5.83(1 \mathrm{H}, \mathrm{d}, \mathrm{br}, J=2.1 \mathrm{~Hz}), 4.20(1 \mathrm{H}, \mathrm{m}$, br), $4.13(1 \mathrm{H}, \mathrm{m}, \mathrm{br}), 3.55(1 \mathrm{H}, \mathrm{d}, \mathrm{br}, J=6.9 \mathrm{~Hz}), 2.83(1 \mathrm{H}, \mathrm{t}, \mathrm{br}, J=$ $8.5 \mathrm{~Hz}), 2.80-240(1 \mathrm{H}, \mathrm{m}, \mathrm{br}), 2.34(1 \mathrm{H}, \mathrm{dd}, J=12.8$ and $4.7 \mathrm{~Hz})$, $2.25(1 \mathrm{H}, \mathrm{m}), 2.21-1.28(32 \mathrm{H}, \mathrm{m}), 1.25(3 \mathrm{H}, \mathrm{s}), 1.24(3 \mathrm{H}, \mathrm{s}), 1.19$ $(1 \mathrm{H}, \mathrm{m}), 1.14(3 \mathrm{H}, \mathrm{s}, \mathrm{br}), 0.98(3 \mathrm{H}, \mathrm{s}), 0.80(3 \mathrm{H}, \mathrm{s}) ;{ }^{13} \mathrm{C}$ NMR $(75$ $\left.\mathrm{MHz} \mathrm{CDCl}_{3}\right) \delta 203.1,168.4,121.4,118.1,117.0,84.9,82.3,76.6$, 72.1, 71.6, 70.4, 50.8, 48.8, 47.4, 41.3, 38.4 (2C), 38.1, 37.9 (2C), $37.0,34.2,31.6,30.9,30.1,29.2,26.6,23.9,23.6,23.4$ (2C), 23.3 (2C), 21.2, 21.1, 20.4, 17.1; (+)-HRESIMS $m / z 635.3911[\mathrm{M}+\mathrm{Na}]^{+}$ (calcd for $\mathrm{C}_{37} \mathrm{H}_{56} \mathrm{O}_{7}, 635.3918$ ).

20-Hydroxyecdysone-2,3,20,22-dicyclohexyl-ketal (9). This was prepared according to GP-A using 20-hydroxyecdysone (1) and cyclohexanone; FC: $n$-hexane-EtOAc, $1: 1$; yield: $59.5 \mathrm{mg}, 93 \%$; white solid; mp 265.6-266.9 ${ }^{\circ} \mathrm{C}$; $[\alpha]^{20}{ }_{\mathrm{D}}+34.0$ (c 1.05, MeOH); ${ }^{1} \mathrm{H}$ $\operatorname{NMR}\left(400 \mathrm{MHz}, \mathrm{CDCl}_{3}\right) \delta 5.82(1 \mathrm{H}, \mathrm{d}, \mathrm{br}, J=2.1 \mathrm{~Hz}), 4.25(1 \mathrm{H}, \mathrm{m}$, 
br), $4.23(1 \mathrm{H}, \mathrm{m}, \mathrm{br}), 3.68(1 \mathrm{H}, \mathrm{d}, \mathrm{br}, J=7.6 \mathrm{~Hz}), 2.82(1 \mathrm{H}, \mathrm{t}, \mathrm{br}, J=$ $8.4 \mathrm{~Hz}), 2.35(1 \mathrm{H}, \mathrm{dd}, J=12.8$ and $4.7 \mathrm{~Hz}), 2.22(1 \mathrm{H}, \mathrm{dd}, J=9.1$ and $7.9 \mathrm{~Hz}), 2.15-1.94(5 \mathrm{H}, \mathrm{m}), 1.89-1.46(28 \mathrm{H}, \mathrm{m}), 1.45-1.29(4 \mathrm{H}$, $\mathrm{m}, \mathrm{br}), 1.25(3 \mathrm{H}, \mathrm{s}), 1.24(3 \mathrm{H}, \mathrm{s}), 1.22(1 \mathrm{H}, \mathrm{m}), 1.16(3 \mathrm{H}, \mathrm{s}, \mathrm{br}), 0.96$ $(3 \mathrm{H}, \mathrm{s}), 082(3 \mathrm{H}, \mathrm{s}) ;{ }^{13} \mathrm{C}$ NMR $\left(75 \mathrm{MHz}, \mathrm{CDCl}_{3}\right) \delta 202.9,165.0$, $121.5,109.0,107.6,83.9,81.8,71.7,77.0,71.2,70.3,50.9,49.0,37.9$, 41.5, 38.6 (2C), 38.5, 38.0, 36.1, 35.6, 34.3, 31.9, 30.0, 28.9, 26.8, 31.0, 25.2, 25.1, 24.2, 24.1, 23.8 (3C), 23.5, 20.5, 21.3, 22.2, 17.1; (+)-HRESIMS $m / z$ 663.4222 $[\mathrm{M}+\mathrm{Na}]^{+}$(calcd for $\mathrm{C}_{39} \mathrm{H}_{60} \mathrm{O}_{7}$, 663.4231).

20-Hydroxyecdysone 2,3,22-triacetate (10). This was prepared according to GP-B using 20-hydroxyecdysone (1) and acetic anhydride; FC: $n$-hexane-EtOAc, 1:9; yield: $48.5 \mathrm{mg}$, $80 \%$; white solid. Spectroscopic data are in accordance with the literature. ${ }^{13}$

Ponasterone A-2,3,22-triacetate (11). This was prepared according to GP-B using ponasterone A (2) and acetic anhydride; FC: $n$-hexane-EtOAc, $1.5: 1$; yield: $46.0 \mathrm{mg}, 78 \%$; white solid; $\mathrm{mp}$ 156.1-157.0 ${ }^{\circ} \mathrm{C} ;[\alpha]^{20}{ }_{\mathrm{D}}+54.3(c 1.01, \mathrm{MeOH}) ;{ }^{1} \mathrm{H}$ NMR $(400 \mathrm{MHz}$, $\left.\mathrm{CDCl}_{3}\right) \delta 5.90(1 \mathrm{H}, \mathrm{d}, \mathrm{br}, J=2.7 \mathrm{~Hz}), 5.39(1 \mathrm{H}, \mathrm{m}, \mathrm{br}), 5.09(1 \mathrm{H}, \mathrm{dt}$, br, $J=11.7$ and $3.9 \mathrm{~Hz}), 4.86(1 \mathrm{H}, \mathrm{dd}, J=10.6$ and $2.1 \mathrm{~Hz}), 3.14$ $(1 \mathrm{H}, \mathrm{t}, \mathrm{br}, J=8.8 \mathrm{~Hz}), 2.42(1 \mathrm{H}, \mathrm{dd}, J=13.3$ and $4.4 \mathrm{~Hz}), 2.39(1 \mathrm{H}$, $\mathrm{t}, J=9.2 \mathrm{~Hz}), 2.22-1.30(17 \mathrm{H}, \mathrm{m}$, methylene and $\mathrm{OH}$ protons $), 2.14$ $(3 \mathrm{H}, \mathrm{s}), 2.13(3 \mathrm{H}, \mathrm{s}), 2.04(3 \mathrm{H}, \mathrm{s}), 1.27(3 \mathrm{H}, \mathrm{s}), 1.19(2 \mathrm{H}, \mathrm{q}, \mathrm{br}, J=$ $7.3 \mathrm{~Hz}), 1.06(3 \mathrm{H}, \mathrm{s}), 0.92(3 \mathrm{H}, \mathrm{d}, J=6.5 \mathrm{~Hz}), 0.91(3 \mathrm{H}, \mathrm{d}, J=6.5$ $\mathrm{Hz}), 0.88(3 \mathrm{H}, \mathrm{s}) ;{ }^{13} \mathrm{C}$ NMR $\left(101 \mathrm{MHz}, \mathrm{CDCl}_{3}\right) \delta 202.6,173.1$, $171.1,170.8,165.1,122.2,85.2,80.0,77.6,69.2,67.6,51.5,50.1,48.1$, 39.0, 36.3, 34.6, 34.2, 32.4, 31.6, 29.8, 28.6, 28.4, 24.4, 23.6, 22.8, 21.7 (4C), 21.1, 21.0, 18.1; (+)-HRESIMS $m / z 613.3353[\mathrm{M}+\mathrm{Na}]^{+}$ (calcd for $\mathrm{C}_{33} \mathrm{H}_{50} \mathrm{O}_{9}, 613.3347$ ).

Makisterone A-2,3,22-triacetate (12). This was prepared according to GP-B using makisterone A (4) and acetic anhydride; FC: $n$-hexane-EtOAc, $1: 1$; yield: $44.6 \mathrm{mg}, 72 \%$; white solid; $\mathrm{mp}$ 219.7-220.6 ${ }^{\circ} \mathrm{C} ;[\alpha]^{20}{ }_{\mathrm{D}}+66.4(c 1.00, \mathrm{MeOH}) ;{ }^{1} \mathrm{H}$ NMR $(400 \mathrm{MHz}$, $\left.\mathrm{CDCl}_{3}\right) \delta 5.89(1 \mathrm{H}, \mathrm{d}, \mathrm{br}, J=2.4 \mathrm{~Hz}), 5.36(1 \mathrm{H}, \mathrm{m}, \mathrm{br}), 5.08(1 \mathrm{H}, \mathrm{dt}$, $\mathrm{br}, J=11.6$ and $3.7 \mathrm{~Hz}), 4.98(1 \mathrm{H}, \mathrm{d}, \mathrm{br}, J=10.1 \mathrm{~Hz}), 3.14(1 \mathrm{H}, \mathrm{t}, \mathrm{br}$, $J=8.2 \mathrm{~Hz}), 2.40(1 \mathrm{H}, \mathrm{dd}, J=13.6$ and $4.2 \mathrm{~Hz}), 2.36(1 \mathrm{H}, \mathrm{t}, J=9.0$ $\mathrm{Hz}), 2.26-1.14(18 \mathrm{H}, \mathrm{m}$, methylene, methyne and $\mathrm{OH}$ protons $), 2.13$ $(3 \mathrm{H}, \mathrm{s}), 2.12(3 \mathrm{H}, \mathrm{s}), 2.02(3 \mathrm{H}, \mathrm{s}), 1.27(3 \mathrm{H}, \mathrm{s}), 1.21(3 \mathrm{H}, \mathrm{s}), 1.18$ $(3 \mathrm{H}, \mathrm{s}), 1.05(3 \mathrm{H}, \mathrm{s}), 0.96(3 \mathrm{H}, \mathrm{d}, J=6.6 \mathrm{~Hz}), 0.88(3 \mathrm{H}, \mathrm{s}) ;{ }^{13} \mathrm{C}$ NMR $\left(75 \mathrm{MHz}, \mathrm{CDCl}_{3}\right) \delta 201.9,172.6,170.5,170.2,164.4,121.6$, 84.6, 77.3, 77.2, 72.9, 68.6, 67.0, 51.0, 49.4, 47.6, 40.6, 38.4, 34.1, 33.6, 32.0, 31.8, 31.1, 29.3, 27.8, 26.2, 23.8, 21.1 (3C), 21.0, 20.4 (2C), 17.5, 14.5; (+)-HRESIMS $m / z 643.3446[\mathrm{M}+\mathrm{Na}]^{+}$(calcd for $\left.\mathrm{C}_{34} \mathrm{H}_{52} \mathrm{O}_{10}, 643.3453\right)$.

Ecdysone 2,3,22-triacetate (13). This was prepared according to GP-B using ecdysone (3) and acetic anhydride; FC: $n$-hexaneEtOAc, 1:1.5; yield: $52.0 \mathrm{mg}$, $88 \%$; white solid; mp $121.3-122.1{ }^{\circ} \mathrm{C}$; $[\alpha]^{20}{ }_{\mathrm{D}}+58.5(c 1.02, \mathrm{MeOH}) ;{ }^{1} \mathrm{H}$ NMR $\left(400 \mathrm{MHz}, \mathrm{CDCl}_{3}\right) \delta 5.89$ $(1 \mathrm{H}, \mathrm{d}, \mathrm{br}, J=2.4 \mathrm{~Hz}), 5.37(1 \mathrm{H}, \mathrm{m}, \mathrm{br}), 5.08(1 \mathrm{H}, \mathrm{dt}, \mathrm{br}, J=12.0$ and $3.6 \mathrm{~Hz}), 4.90(1 \mathrm{H}, \mathrm{dt}, \mathrm{br}, J=9.7 \mathrm{and} 2.6 \mathrm{~Hz}), 3.13(1 \mathrm{H}, \mathrm{t}, \mathrm{br}, J=$ $8.2 \mathrm{~Hz}), 2.40(1 \mathrm{H}, \mathrm{dd}, J=12.9$ and $4.1 \mathrm{~Hz}), 2.24-1.30(20 \mathrm{H}, \mathrm{m}$, methylene, methyne and $\mathrm{OH}$ protons), $2.12(3 \mathrm{H}, \mathrm{s}), 2.07(3 \mathrm{H}, \mathrm{s})$, $2.02(3 \mathrm{H}, \mathrm{s}), 1.25(3 \mathrm{H}, \mathrm{s}), 1.24(3 \mathrm{H}, \mathrm{s}), 1.04(3 \mathrm{H}, \mathrm{s}), 0.96(3 \mathrm{H}, \mathrm{d}, J=$ $6.7 \mathrm{~Hz}), 0.68(3 \mathrm{H}, \mathrm{s}) ;{ }^{13} \mathrm{C} \mathrm{NMR}\left(75 \mathrm{MHz}, \mathrm{CDCl}_{3}\right) \delta 202.8,171.7$, 171.2 , 170.9, 165.1, 122.1, 85.1, 77.9, 71.4, 69.3, 67.7, 51.6, 48.0, 47.6, 41.1, 39.7, 39.1, 34.7, 34.4, 32.7, 31.2, 30.6, 29.9, 29.6, 26.1, 24.5, 22.6, 22.1, 21.8, 21.7, 21.1, 16.4, 14.1; (+)-HRESIMS $\mathrm{m} / z 613.3339$ $[\mathrm{M}+\mathrm{Na}]^{+}$(calcd for $\left.\mathrm{C}_{33} \mathrm{H}_{50} \mathrm{O}_{9}, 613.3347\right)$.

20-Hydroxyecdysone 2,3,22-tribenzoate (14). This was prepared according to GP-B using 20-hydroxyecdysone (1) and benzoyl chloride; FC: $n$-hexane-EtOAc, $1: 1.5$; yield: $69.0 \mathrm{mg}, 87 \%$; white solid; mp $148.5-149.0^{\circ} \mathrm{C}$; $[\alpha]^{20}{ }_{\mathrm{D}}+15.7$ (c 1.13, MeOH); ${ }^{1} \mathrm{H}$ NMR $\left(400 \mathrm{MHz}, \mathrm{CDCl}_{3}\right) \delta 8.10(4 \mathrm{H}, \mathrm{d}, \mathrm{br}, J=7.6 \mathrm{~Hz}), 7.88(2 \mathrm{H}, \mathrm{d}$, $\mathrm{br}, J=7.4 \mathrm{~Hz}), 7.64-7.55(2 \mathrm{H}, \mathrm{m}), 7.53-7.43(5 \mathrm{H}, \mathrm{m}), 7.33(2 \mathrm{H}, \mathrm{t}$, br, $J=7.8 \mathrm{~Hz}), 5.99(1 \mathrm{H}, \mathrm{d}, \mathrm{br}, J=1.9 \mathrm{~Hz}), 5.73(1 \mathrm{H}, \mathrm{m}, \mathrm{br}), 5.51$ $(1 \mathrm{H}, \mathrm{dt}, \mathrm{br}, J=12.2$ and $3.2 \mathrm{~Hz}), 5.19(1 \mathrm{H}, \mathrm{d}, \mathrm{br}, J=10.3 \mathrm{~Hz}), 4.05-$ $2.99(3 \mathrm{H}, \mathrm{m}, \mathrm{br}), 3.38(1 \mathrm{H}, \mathrm{t}, \mathrm{br}, J=7.9 \mathrm{~Hz}), 2.59(1 \mathrm{H}, \mathrm{dd}, J=12.8$ and $4.7 \mathrm{~Hz}), 2.53(1 \mathrm{H}, \mathrm{m}), 2.36-1.49(16 \mathrm{H}, \mathrm{m}), 1.45(3 \mathrm{H}, \mathrm{s}), 1.24$ $(3 \mathrm{H}, \mathrm{s}), 1.23(3 \mathrm{H}, \mathrm{s}), 1.15(3 \mathrm{H}, \mathrm{s}, \mathrm{br}), 0.93(3 \mathrm{H}, \mathrm{s}) ;{ }^{13} \mathrm{C}$ NMR $(101$ $\left.\mathrm{MHz}, \mathrm{CDCl}_{3}\right) \delta 202.4,167.7,165.9,165.7,165.2,133.3$ (2C), 133.1,
130.2, 130.1, 129.9, 129.8 (2C), 129.7 (2C), 129.6 (3C), 128.6 (2C), 128.4, 128.3 (2C), 121.6, 84.6, 80.6, 77.3, 70.8, 69.8, 68.2, 51.5, 49.7, $47.7,40.3,38.6,34.6,33.8,31.3$ (2C), 30.4, 29.4, 28.3, 25.0, 24.0, 21.6, 20.6 (2C), 17.5; (+)-HRESIMS $m / z 815.3754[\mathrm{M}+\mathrm{Na}]^{+}$ (calcd for $\mathrm{C}_{48} \mathrm{H}_{56} \mathrm{O}_{10}, 815.3766$ ).

Ponasterone A-2,3,22-tribenzoate (15). This was prepared according to GP-B using ponasterone A (2) and benzoyl chloride; FC: $n$-hexane-EtOAc, $1: 1$; yield: $56.5 \mathrm{mg}, 73 \%$; white solid; $\mathrm{mp}$ $118.8-119.7^{\circ} \mathrm{C} ;[\alpha]^{20}{ }_{\mathrm{D}}+18.3(\mathrm{c} 0.90, \mathrm{MeOH}) ;{ }^{1} \mathrm{H}$ NMR $(400 \mathrm{MHz}$, $\left.\mathrm{CDCl}_{3}\right) \delta 8.15-8.06(4 \mathrm{H}, \mathrm{m}), 7.91(2 \mathrm{H}, \mathrm{d}, \mathrm{br}, J=7.8 \mathrm{~Hz}), 7.66-7.57$ $(2 \mathrm{H}, \mathrm{m}), 7.54-7.44(5 \mathrm{H}, \mathrm{m}), 7.36(2 \mathrm{H}, \mathrm{t}, \mathrm{br}, J=7.8 \mathrm{~Hz}), 5.97(1 \mathrm{H}$, d, $J=2.2 \mathrm{~Hz}), 5.75(1 \mathrm{H}, \mathrm{m}, \mathrm{br}), 5.48(1 \mathrm{H}, \mathrm{dt}, \mathrm{br}, J=12.0$ and 3.3 $\mathrm{Hz}), 5.17(1 \mathrm{H}, \mathrm{dd}, \mathrm{br}, J=10.5$ and $2.2 \mathrm{~Hz}), 3.34(1 \mathrm{H}, \mathrm{t}, \mathrm{br}, J=7.9$ $\mathrm{Hz}), 2.60(1 \mathrm{H}, \mathrm{dd}, J=13.2$ and $3.9 \mathrm{~Hz}), 2.54-2.47(1 \mathrm{H}, \mathrm{m}), 2.35-$ $1.50(16 \mathrm{H}, \mathrm{m}), 1.40(3 \mathrm{H}, \mathrm{s}), 1.33-1.22(3 \mathrm{H}, \mathrm{m}), 1.15(3 \mathrm{H}, \mathrm{s}, \mathrm{br})$, $0.93(3 \mathrm{H}, \mathrm{s}), 0.90(6 \mathrm{H}, \mathrm{d}, J=6.6 \mathrm{~Hz}) ;{ }^{13} \mathrm{C}$ NMR $\left(101 \mathrm{MHz}, \mathrm{CDCl}_{3}\right)$ $\delta 201.9,167.7,165.9,165.7,164.7,133.3,133.2(2 \mathrm{C}), 130.2(2 \mathrm{C})$, $129.9,129.7$ (4C), 129.6 (2C), 128.6 (2C), 128.5 (2C), $128.4(2 \mathrm{C})$, $121.7,84.7,80.0,77.4,69.7,68.1,51.4,49.7,47.6,38.7,35.7,34.6$, $33.8,31.9,31.2,29.4,28.2,27.8,24.0,23.0,22.2,21.5,20.6,20.5$, 17.6; (+)-HRESIMS $m / z 799.3812[\mathrm{M}+\mathrm{Na}]^{+}\left(\right.$calcd for $\mathrm{C}_{48} \mathrm{H}_{56} \mathrm{O}_{9}$, 799.3817).

20-Hydroxyecdysone 2,22-dihexanoate (16). This was prepared according to GP-B using 20-hydroxyecdysone (1) and hexanoyl chloride; FC: $n$-hexane-EtOAc, $1: 1.5$; yield: $52.0 \mathrm{mg}, 77 \%$; white solid; mp $101.4-102.7^{\circ} \mathrm{C}$; $[\alpha]^{20}{ }_{\mathrm{D}}+37.3(\mathrm{c} 1.02, \mathrm{MeOH}) ;{ }^{1} \mathrm{H}$ $\operatorname{NMR}\left(400 \mathrm{MHz}, \mathrm{CDCl}_{3}\right) \delta 5.88(1 \mathrm{H}, \mathrm{d}, \mathrm{br}, J=2.4 \mathrm{~Hz}), 5.04(1 \mathrm{H}, \mathrm{dt}$, br, $J=11.5$ and $3.8 \mathrm{~Hz}), 4.88(1 \mathrm{H}, \mathrm{dd}, J=10.3$ and $2.2 \mathrm{~Hz}), 4.14$ $(1 \mathrm{H}, \mathrm{m}, \mathrm{br}), 3.13(1 \mathrm{H}, \mathrm{t}, \mathrm{br}, J=8.1 \mathrm{~Hz}), 2.53(1 \mathrm{H}, \mathrm{dd}, J=13.5$ and $4.1 \mathrm{~Hz}), 2.45-2.32(5 \mathrm{H}, \mathrm{m}), 2.21-1.21(41 \mathrm{H}, \mathrm{m}), 1.01(3 \mathrm{H}, \mathrm{s})$, 0.95-089 (6H, m), $0.87(3 \mathrm{H}, \mathrm{s}) ;{ }^{13} \mathrm{C}$ NMR $\left(101 \mathrm{MHz}, \mathrm{CDCl}_{3}\right) \delta$ $203.0,175.3,173.1,164.3,122.4,84.7,79.1,76.5,70.7,68.6,65.8$, $49.9,49.6,47.5,40.4,39.2,34.5$ (2C), 33.7, 33.0, 31.7, $31.3(2 \mathrm{C})$, 31.1, 30.1, 29.4, 28.8, 24.8, 24.7, 24.5, 23.9, 22.3 (2C), 21.2, 20.6, 20.3, 17.5, 13.9 (2C); (+)-HRESIMS $m / z 699.4449[\mathrm{M}+\mathrm{Na}]^{+}$ (calcd for $\mathrm{C}_{39} \mathrm{H}_{64} \mathrm{O}_{9}, 699.4443$ ).

20-Hydroxyecdysone 2,22-dicinnamate (17). This was prepared according to GP-B using 20-hydroxyecdysone (1) and cinnamoyl chloride; FC: $n$-hexane-EtOAc, 3:7; yield: $63.0 \mathrm{mg}, 85 \%$; white solid; mp $161.8-162.5{ }^{\circ} \mathrm{C}$; $[\alpha]^{20}{ }_{\mathrm{D}}+6.6(c 0.77, \mathrm{MeOH}) ;{ }^{1} \mathrm{H}$ $\operatorname{NMR}\left(400 \mathrm{MHz}, \mathrm{CDCl}_{3}\right) \delta 7.74(1 \mathrm{H}, \mathrm{d}, J=15.9 \mathrm{~Hz}), 7.73(1 \mathrm{H}, \mathrm{d}, J$ $=15.9 \mathrm{~Hz}), 7.60-7.51(4 \mathrm{H}, \mathrm{m}), 7.45-7.38(6 \mathrm{H}, \mathrm{m}), 6.51(1 \mathrm{H}, \mathrm{d}, J=$ $15.9 \mathrm{~Hz}), 6.49(1 \mathrm{H}, \mathrm{d}, J=15.9 \mathrm{~Hz}), 5.92(1 \mathrm{H}, \mathrm{d}, \mathrm{br}, J=2.4 \mathrm{~Hz}), 5.18$ $(1 \mathrm{H}, \mathrm{dt}, \mathrm{br}, J=11.2$ and $3,5 \mathrm{~Hz}), 5.04(1 \mathrm{H}, \mathrm{dd}, \mathrm{br}, J=10.3$ and 1.7 $\mathrm{Hz}), 4.24(1 \mathrm{H}, \mathrm{m}, \mathrm{br}), 3.21(1 \mathrm{H}, \mathrm{t}, \mathrm{br}, J=8.3 \mathrm{~Hz}), 2.58(1 \mathrm{H}, \mathrm{dd}, J=$ 13.2 and $3.9 \mathrm{~Hz}), 2.46(1 \mathrm{H}, \mathrm{m}), 2.21(1 \mathrm{H}, \mathrm{dt}, J=13.2$ and $4.4 \mathrm{~Hz})$, 2.16-1.41 (19H, m), $1.37(3 \mathrm{H}, \mathrm{s}), 1.26(3 \mathrm{H}, \mathrm{s}), 1.24(3 \mathrm{H}, \mathrm{s}), 1.05$ $(3 \mathrm{H}, \mathrm{s}, \mathrm{br}), 0.91(3 \mathrm{H}, \mathrm{s}) ;{ }^{13} \mathrm{C}$ NMR $\left(101 \mathrm{MHz}, \mathrm{CDCl}_{3}\right) \delta 203.1$, $168.2,166.3,164.5,145.7,145.6,134.3,134.2,130.5,130.4,129.0$ (2C), 128.9 (2C), 128.2 (4C), 121.9, 117.9, 117.8, 84.7, 79.9, 77.2, 71.6, 70.7, 65.7, 50.0, 49.7, 47.6, 40.3, 38.6, 33.6, 33.1, 31.7, 31.3 (2C), 30.3, 28.7, 25.0, 23.8, 21.5, 20.6, 20.4, 17.5; (+)-HRESIMS $\mathrm{m} / \mathrm{z}$ $763.3826[\mathrm{M}+\mathrm{Na}]^{+}\left(\right.$calcd for $\left.\mathrm{C}_{45} \mathrm{H}_{56} \mathrm{O}_{9}, 763.3817\right)$.

20-Hydroxyecdysone 2,3,22,25-tetraacetate (18). This was prepared according to GP-C using 20-hydroxyecdysone (1) and acetyl chloride; FC: $n$-hexane-EtOAc, 1:9; yield: $43.5 \mathrm{mg}, 67 \%$; white solid; mp 103.3-103.5 ${ }^{\circ} \mathrm{C} ;[\alpha]^{20}{ }_{\mathrm{D}}+54.4(c$ 1.05, MeOH$) ;{ }^{1} \mathrm{H}$ NMR $(400$ $\left.\mathrm{MHz}, \mathrm{CDCl}_{3}\right) \delta 5.89(1 \mathrm{H}, \mathrm{d}, \mathrm{br}, J=2.4 \mathrm{~Hz}), 5.37(1 \mathrm{H}, \mathrm{m}, \mathrm{br}), 5.09$ $(1 \mathrm{H}, \mathrm{dt}, \mathrm{br}, J=11.8$ and $3.7 \mathrm{~Hz}), 4.83(1 \mathrm{H}, \mathrm{dd}, \mathrm{br}, J=9.9$ and 2.0 $\mathrm{Hz}), 3.14(1 \mathrm{H}, \mathrm{t}, \mathrm{br}, J=8.4 \mathrm{~Hz}), 2.40(1 \mathrm{H}, \mathrm{dd}, J=13.4$ and $4.2 \mathrm{~Hz})$, $2.38(1 \mathrm{H}, \mathrm{t}, J=8.8 \mathrm{~Hz}), 2.17(1 \mathrm{H}, \mathrm{dd}, J=12.7$ and $4.8 \mathrm{~Hz}), 2.15-$ $1.47(17 \mathrm{H}, \mathrm{m}$, methylene and $\mathrm{OH}$ protons $), 2.14(3 \mathrm{H}, \mathrm{s}), 2.13(3 \mathrm{H}$ s), $2.02(3 \mathrm{H}, \mathrm{s}), 2.00(3 \mathrm{H}, \mathrm{s}), 1.46(3 \mathrm{H}, \mathrm{s}), 1.42(3 \mathrm{H}, \mathrm{s}), 1.27(3 \mathrm{H}, \mathrm{s})$, $1.05(3 \mathrm{H}, \mathrm{s}), 0.87(3 \mathrm{H}, \mathrm{s}) ;{ }^{13} \mathrm{C}$ NMR $\left(75 \mathrm{MHz}, \mathrm{CDCl}_{3}\right) \delta 202.1$, 172.4, 170.6 (2C), 170.3, 164.6, 121.6, 84.5, 81.8, 79.4, 68.6, 67.0, $50.9,49.6,47.4,38.3,37.5,34.0,33.6,31.6,31.1,29.2,26.3,25.9$, 24.6, 23.8, 22.4, 21.1 (4C), 20.6, 20.4, 17.4; (+)-HRESIMS $m / z[\mathrm{M}+$ $\mathrm{Na}]^{+} 671.3408$ (calcd for $\mathrm{C}_{35} \mathrm{H}_{52} \mathrm{O}_{11}, 671.3402$ ).

Makisterone A-2,3,22,25-tetraacetate (19). This was prepared according to GP-C using makisterone A (4) and acetyl chloride; FC: 
n-hexane-EtOAc, 1:1; yield: $43.0 \mathrm{mg}, 65 \%$; white solid; mp $111.1-$ $111.9{ }^{\circ} \mathrm{C} ;[\alpha]_{\mathrm{D}}^{20}+62.3(\mathrm{c} 1.03, \mathrm{MeOH}) ;{ }^{1} \mathrm{H}$ NMR $(400 \mathrm{MHz}$, $\left.\mathrm{CDCl}_{3}\right) \delta 5.90(1 \mathrm{H}, \mathrm{d}, \mathrm{br}, J=2.4 \mathrm{~Hz}), 5.38(1 \mathrm{H}, \mathrm{m}, \mathrm{br}), 5.09(1 \mathrm{H}, \mathrm{dt}$, br, $J=12.0$ and $3.7 \mathrm{~Hz}), 4.95(1 \mathrm{H}, \mathrm{d}, \mathrm{br}, J=10.3 \mathrm{~Hz}), 3.14(1 \mathrm{H}, \mathrm{m}$, br), $2.42(1 \mathrm{H}, \mathrm{dd}, J=13.4$ and $3.9 \mathrm{~Hz}), 2.35(1 \mathrm{H}, \mathrm{t}, J=9.4 \mathrm{~Hz})$, $2.22-1.10(17 \mathrm{H}, \mathrm{m}$, methylene, methyne, and $\mathrm{OH}$ protons $), 2.14$ $(3 \mathrm{H}, \mathrm{s}), 2.13(3 \mathrm{H}, \mathrm{s}), 2.03(3 \mathrm{H}, \mathrm{s}), 2.00(3 \mathrm{H}, \mathrm{s}), 1.46(3 \mathrm{H}, \mathrm{s}), 1.37$ $(3 \mathrm{H}, \mathrm{s}), 1.26(3 \mathrm{H}, \mathrm{s}), 1.06(3 \mathrm{H}, \mathrm{s}), 0.95(3 \mathrm{H}, \mathrm{d}, J=6.8 \mathrm{~Hz}), 0.88$ $(3 \mathrm{H}, \mathrm{s}, \mathrm{br}) ;{ }^{13} \mathrm{C} \mathrm{NMR}\left(75 \mathrm{MHz}, \mathrm{CDCl}_{3}\right) \delta 202.0,172.8,172.5,170.5$, $170.2,164.4,121.6,84.9,84.5,77.0,76.8,68.6,67.0,50.9,49.4,47.5$, $38.4,37.2$, 34.0, 33.6, 32.0, 31.8, 31.1, 29.2, 24.2, 23.8, 22.8, 22.6, 22.5, 21.1 (3C), $20.4(2 \mathrm{C}), 17.5,14.4$; (+)-HRESIMS $m / z 685.3564$ $[\mathrm{M}+\mathrm{Na}]^{+}$(calcd for $\mathrm{C}_{36} \mathrm{H}_{54} \mathrm{O}_{11}, 685.3558$ ).

Ecdysone 2,3,22,25-tetraacetate (20). This was prepared according to GP-C using ecdysone (3) and acetyl chloride; FC: $n$ hexane-EtOAc, 1:1.5; yield: $48.5 \mathrm{mg}$, 77\%; white solid; mp 101.1$101.9^{\circ} \mathrm{C} ;[\alpha]^{20}{ }_{\mathrm{D}}+58.3(c 1.0, \mathrm{MeOH}) ;{ }^{1} \mathrm{H}$ NMR $\left(300 \mathrm{MHz}, \mathrm{CDCl}_{3}\right)$ $\delta 5.90(1 \mathrm{H}, \mathrm{d}, \mathrm{br}, J=2.1 \mathrm{~Hz}), 5.39(1 \mathrm{H}, \mathrm{m}, \mathrm{br}), 5.10(1 \mathrm{H}, \mathrm{dt}, \mathrm{br}, J=$ 12.0 and $3.2 \mathrm{~Hz}), 4.87(1 \mathrm{H}, \mathrm{m}, \mathrm{br}), 3.13(1 \mathrm{H}, \mathrm{t}, \mathrm{br}, J=8.6 \mathrm{~Hz}), 2.42$ $(1 \mathrm{H}, \mathrm{dd}, J=13.4$ and $4.1 \mathrm{~Hz}), 2.20-1.14(19 \mathrm{H}, \mathrm{m}$, methylene, methyne, and $\mathrm{OH}$ protons), $2.13(3 \mathrm{H}, \mathrm{s}), 2.08(3 \mathrm{H}, \mathrm{s}), 2.03(3 \mathrm{H}, \mathrm{s})$, $2.01(3 \mathrm{H}, \mathrm{s}), 1.47(3 \mathrm{H}, \mathrm{s}), 1.46(3 \mathrm{H}, \mathrm{s}), 1.06(3 \mathrm{H}, \mathrm{s}), 0.96(3 \mathrm{H}, \mathrm{d}, J=$ $6.5 \mathrm{~Hz}), 0.69(3 \mathrm{H}, \mathrm{s}) ;{ }^{13} \mathrm{C} \mathrm{NMR}\left(75 \mathrm{MHz}, \mathrm{CDCl}_{3}\right) \delta 202.7,171.6$, 171.2 (2C), 170.8, 164.8, 122.2, 85.2, 82.7, 77.6, 69.3, 67.6, 51.6, 48.0, 47.6, 39.5, 39.1, 38.2, 34.7, 34.4, 32.8, 31.2, 30.0, 26.9, 26.7, 26.0, 24.6, 22.4, 22.1, 21.8 (3C), 21.1, 16.4, 14.0; (+)-HRESIMS $\mathrm{m} / \mathrm{z}$ $655.3458[\mathrm{M}+\mathrm{Na}]^{+}$(calcd for $\left.\mathrm{C}_{35} \mathrm{H}_{52} \mathrm{O}_{10}, 655.3453\right)$.

Ajugasterone C-2,3,11,22-tetraacetate (21). This was prepared according to GP-C using ajugasterone C (5) and acetyl chloride; FC: $n$-hexane-EtOAc, 1:9; yield: $59.0 \mathrm{mg}$, $91 \%$; white solid; mp 106.4-107.3 ${ }^{\circ} \mathrm{C}$; $[\alpha]^{20}+44.6(c 1.05, \mathrm{MeOH}) ;{ }^{1} \mathrm{H}$ NMR (400 $\left.\mathrm{MHz}, \mathrm{CDCl}_{3}\right) \delta 5.94(1 \mathrm{H}, \mathrm{d}, \mathrm{br}, J=2.6 \mathrm{~Hz}), 5.42(1 \mathrm{H}, \mathrm{m}, \mathrm{br}), 5.34-$ $5.25(2 \mathrm{H}, \mathrm{m}, \mathrm{br}), 4.83(1 \mathrm{H}, \mathrm{dd}, \mathrm{br}, J=10.5$ and $1.8 \mathrm{~Hz}), 3.44(1 \mathrm{H}$, $\mathrm{dd} J=8.5$ and $2.3 \mathrm{~Hz}), 2.44-2.33(3 \mathrm{H}, \mathrm{m}), 2.17-1.09(16 \mathrm{H}, \mathrm{m}$, methylene and $\mathrm{OH}$ protons), $2.13(3 \mathrm{H}, \mathrm{s}), 2.12(3 \mathrm{H}, \mathrm{s}), 2.00(3 \mathrm{H}, \mathrm{s})$, $1.97(3 \mathrm{H}, \mathrm{s}), 1.25(3 \mathrm{H}, \mathrm{s}), 1.12(3 \mathrm{H}, \mathrm{s}), 0.91(3 \mathrm{H}, \mathrm{s}), 0.90(3 \mathrm{H}, \mathrm{d}, J=$ $6.5 \mathrm{~Hz}), 0.89(3 \mathrm{H}, \mathrm{d}, J=6.5 \mathrm{~Hz}) ;{ }^{13} \mathrm{C}$ NMR $\left(101 \mathrm{MHz}, \mathrm{CDCl}_{3}\right) \delta$ 201.9, 173.1, 171.1, 170.9, 170.8, 161.9, 123.6, 84.6, 79.9, 77.4, 71.9, $69.2,67.4,52.2,50.0,47.9,40.0,38.9,38.1,36.5,36.3,32.3,29.9$, 28.6, 28.5, 24.5, 23.6, 22.8, 21.9, 21.8 (3C), 21.6, 21.2, 18.7; $(+)$-HRESIMS $m / z$ 671.3412 $[\mathrm{M}+\mathrm{Na}]^{+}$(calcd for $\mathrm{C}_{35} \mathrm{H}_{52} \mathrm{O}_{11}$, 671.3402)

20-Hydroxyecdysone 2,3,22,25-tetrabenzoate (22). This was prepared according to GP-C using 20-hydroxyecdysone (1) and benzoyl chloride; FC: $n$-hexane-EtOAc, $1: 1.5$; yield: $53.0 \mathrm{mg}, 59 \%$; white solid; mp $126.9-127 .{ }^{\circ} \mathrm{C}$; $[\alpha]^{20}{ }_{\mathrm{D}}+13.9$ (c 1.04, MeOH); ${ }^{1} \mathrm{H}$ NMR $\left(400 \mathrm{MHz}, \mathrm{CDCl}_{3}\right) \delta 8.17-8.06(4 \mathrm{H}, \mathrm{m}), 8.01(2 \mathrm{H}, \mathrm{d}, \mathrm{br}, J=$ $7.5 \mathrm{~Hz}), 7.91(2 \mathrm{H}, \mathrm{d}, \mathrm{br}, J=7.5 \mathrm{~Hz}), 7.67-7.39(10 \mathrm{H}, \mathrm{m}), 7.35(2 \mathrm{H}$, t, br, $J=7.6 \mathrm{~Hz}), 5.95(1 \mathrm{H}, \mathrm{s}, \mathrm{br}), 5.70(1 \mathrm{H}, \mathrm{m}, \mathrm{br}), 5.44(1 \mathrm{H}, \mathrm{d}, \mathrm{br}, J$ $=11.6 \mathrm{~Hz}), 5.20(1 \mathrm{H}, \mathrm{d}, \mathrm{br}, J=10.0 \mathrm{~Hz}), 3.32(1 \mathrm{H}, \mathrm{m}, \mathrm{br}), 2.64-2.37$ $(1 \mathrm{H}, \mathrm{m}), 2.58(1 \mathrm{H}, \mathrm{dd}, J=13.2$ and $3.0 \mathrm{~Hz}), 2.51(1 \mathrm{H}, \mathrm{m}), 2.34-$ $1.57(17 \mathrm{H}, \mathrm{m}), 1.62(3 \mathrm{H}, \mathrm{s}), 1.59(3 \mathrm{H}, \mathrm{s}), 1.41(3 \mathrm{H}, \mathrm{s}), 1.13(3 \mathrm{H}, \mathrm{s}$, br), $0.91(3 \mathrm{H}, \mathrm{s}) ;{ }^{13} \mathrm{C} \mathrm{NMR}\left(101 \mathrm{MHz}, \mathrm{CDCl}_{3}\right) \delta 202.0,167.6,165.9$ 165.7 (2C), 164.9, 133.3 (2C), 133.2, 132.7, 131.7, 130.2, 130.1, $129.9,129.8$ (2C), 129.7 (2C), 129.6 (2C), 129.5 (2C), $128.6(3 \mathrm{C})$, 128.4 (5C), 121.6, 84.4, 82.5, 80.1, 77.2, 69.7, 68.1, 51.4, 49.7, 47.6, 38.6, 38.5, 34.6, 33.7, 31.6, 31.2, 29.4, 26.3, 25.9, 25.0, 24.0, 21.6, 20.7, 20.5, 17.5; (+)-HRESIMS $m / z 919.4019[\mathrm{M}+\mathrm{Na}]^{+}$(calcd for $\left.\mathrm{C}_{55} \mathrm{H}_{60} \mathrm{O}_{11}, 919.4028\right)$.

20-Hydroxyecdysone 2,3,22-trihexanoate (23). This was prepared according to GP-C using 20-hydroxyecdysone (1) and hexanoyl chloride; FC: $n$-hexane-EtOAc, 1:1.5; yield: $52.5 \mathrm{mg}, 68 \%$; white solid; foam; $[\alpha]^{20}{ }_{\mathrm{D}}+31.4\left(c\right.$ 0.99, MeOH); ${ }^{1} \mathrm{H}$ NMR $(400$ $\left.\mathrm{MHz} \mathrm{CDCl}_{3}\right) \delta 5.89(1 \mathrm{H}, \mathrm{d}, \mathrm{br}, J=2.0 \mathrm{~Hz}), 5.39(1 \mathrm{H}, \mathrm{m}, \mathrm{br}), 5.10$ $(1 \mathrm{H}, \mathrm{dt}, \mathrm{br}, J=12.0$ and $3.5 \mathrm{~Hz}), 4.88(1 \mathrm{H}, \mathrm{d}, \mathrm{br}, J=10.5 \mathrm{~Hz}), 3.15$ $(1 \mathrm{H}, \mathrm{t}, \mathrm{br}, J=8.1 \mathrm{~Hz}), 2.62-2.31(7 \mathrm{H}, \mathrm{m}), 2.27-1.17(47 \mathrm{H}, \mathrm{m}), 1.05$ $(3 \mathrm{H}, \mathrm{s}), 0.98-088(9 \mathrm{H}, \mathrm{m}), 0.87(3 \mathrm{H}, \mathrm{s}) ;{ }^{13} \mathrm{C}$ NMR $(101 \mathrm{MHz}$, $\left.\mathrm{CDCl}_{3}\right) \delta 202.8,176.1,173.9,173.6,165.1,122.3,85.3,80.1,77.8$, 71.3, 69.2, 67.4, 51.7, 50.2, 48.2, 41.0, 39.1, 35.2, 35.1, 34.9, 34.8, $34.2,32.4,32.0,31.9(2 \mathrm{C}), 31.8,30.8,30.0,29.5,25.5,25.4(2 \mathrm{C})$,
$25.1,24.5,23.0$ (3C), 21.9, 21.2, 21.0, 18.2, 14.6 (3C); (+)-HRESIMS $m / z$ 797.5166 $[\mathrm{M}+\mathrm{Na}]^{+}$(calcd for $\mathrm{C}_{45} \mathrm{H}_{74} \mathrm{O}_{10}$, 797.5174).

20-Hydroxyecdysone 2,3,22-trilaurate (24). This was prepared according to GP-C using 20-hydroxyecdysone (1) and lauryl chloride; FC: $n$-hexane-EtOAc, 1:1.5; yield: $58.5 \mathrm{mg}, 57 \%$; colorless thick oil; $[\alpha]_{\mathrm{D}}^{20}+25.0(c 0.55, \mathrm{MeOH}) ;{ }^{1} \mathrm{H}$ NMR $\left(400 \mathrm{MHz}, \mathrm{CDCl}_{3}\right)$ $\delta 5.89(1 \mathrm{H}, \mathrm{d}, \mathrm{br}, J=2.0 \mathrm{~Hz}), 5.39(1 \mathrm{H}, \mathrm{m}, \mathrm{br}), 5.10(1 \mathrm{H}, \mathrm{dt}, \mathrm{br}, J=$ 12.3 and $3.5 \mathrm{~Hz}), 4.88(1 \mathrm{H}, \mathrm{d}, \mathrm{br}, J=10.5 \mathrm{~Hz}), 3.15(1 \mathrm{H}, \mathrm{t}, \mathrm{br}, J=7.9$ $\mathrm{Hz}), 2.44-2.32(8 \mathrm{H}, \mathrm{m}), 2.25(1 \mathrm{H}, \mathrm{t}, J=7.7 \mathrm{~Hz}), 2.20-1.25(75 \mathrm{H}$, $\mathrm{m}), 1.25(3 \mathrm{H}, \mathrm{s}), 1.23(3 \mathrm{H}, \mathrm{s}), 1.04(3 \mathrm{H}, \mathrm{s}), 0.99(9 \mathrm{H}, \mathrm{t}, J=6.8 \mathrm{~Hz})$, $0.87(3 \mathrm{H}, \mathrm{s}) ;{ }^{13} \mathrm{C}$ NMR $\left(101 \mathrm{MHz}, \mathrm{CDCl}_{3}\right) \delta 202.7,176.1,173.8$, $173.5,165.1,122.3,85.2,80.1,77.7,71.3,69.2,67.4,51.7,50.2,48.2$, $41.0,39.1,35.3,35.2$, 35.0, 34.9, 34.2, 32.6 (3C), 32.4, 31.7, 30.8, 30.3-29.8 (19C), 29.5, 25.8 (2C), 25.5, 25.4 (1C), 24.5, 23.4 (3C), 21.9, 21.2, 21.0, 18.1, 14.8 (3C); (+)-HRESIMS $\mathrm{m} / z$ 1049.7998 [M + $\mathrm{Na}]^{+}$(calcd for $\mathrm{C}_{63} \mathrm{H}_{110} \mathrm{O}_{10}, 1049.7991$ ).

Ponasterone A-2,3,22-trilaurate (25). This was prepared according to GP-C using ponasterone A (2) and lauryl chloride; FC: $n$-hexane-EtOAc, $1: 1.5$; yield: $60.0 \mathrm{mg}, 59 \%$; colorless thick oil; $[\alpha]^{20}{ }_{\mathrm{D}}+15.4(c 0.51, \mathrm{MeOH}) ;{ }^{1} \mathrm{H}$ NMR $\left(400 \mathrm{MHz}, \mathrm{CDCl}_{3}\right) \delta 5.90$ $(1 \mathrm{H}, \mathrm{d}, \mathrm{br}, J=2.4 \mathrm{~Hz}), 5.39(1 \mathrm{H}, \mathrm{m}, \mathrm{br}), 5.11(1 \mathrm{H}, \mathrm{dt}, \mathrm{br}, J=12.0$ and $3.5 \mathrm{~Hz}), 4.87(1 \mathrm{H}, \mathrm{dd}, J=10.5$ and $2.0 \mathrm{~Hz}), 3.16(1 \mathrm{H}, \mathrm{t}, \mathrm{br}, J=$ $8.3 \mathrm{~Hz}), 2.45-2.33(6 \mathrm{H}, \mathrm{m}), 2.26(2 \mathrm{H}, \mathrm{t}, \mathrm{br}, J=7.6 \mathrm{~Hz}), 2.21-1.14$ $(76 \mathrm{H}, \mathrm{m}), 1.05(3 \mathrm{H}, \mathrm{s}), 0.91(6 \mathrm{H}, \mathrm{d}, J=6.6 \mathrm{~Hz}), 0.90(9 \mathrm{H}, \mathrm{t}, J=6.9$ $\mathrm{Hz}), 0.88(3 \mathrm{H}, \mathrm{s}) ;{ }^{13} \mathrm{C} \mathrm{NMR}\left(101 \mathrm{MHz}, \mathrm{CDCl}_{3}\right) \delta 202.0,17.5,173.2$, $172.9,164.3,121.7,84.7,79.1,77.2,68.5,66.7,51.1,49.6,47.5,38.5$, $35.7,34.5,34.2$, 33.9 (2C), 33.6, 31.9 (4C), 31.1, 29.7-29.1 (20C), 27.7, 25.1, 24.7 (2C), 23.9, 26.6, 22.7 (3C), 22.2, 21.1, 20.5, 20.4, $17.5,14.1(3 \mathrm{C}) ;(+)$-HRESIMS $m / z 1033.8031[\mathrm{M}+\mathrm{Na}]^{+}$(calcd for $\left.\mathrm{C}_{63} \mathrm{H}_{110} \mathrm{O}_{9}, 1033.8042\right)$.

20-Hydroxyecdysone 2,3,22-tricinnamate (26). This was prepared according to GP-C using 20-hydroxyecdysone (1) and cinnamoyl chloride; FC: $n$-hexane-EtOAc, $3: 7$; yield: $48.0 \mathrm{mg}$, $55 \%$; white solid; mp $157.2-158{ }^{\circ} \mathrm{C}$; $[\alpha]^{20}{ }_{\mathrm{D}}-47.9$ (c 1.01, MeOH); ${ }^{1} \mathrm{H}$ NMR $\left(400 \mathrm{MHz}, \mathrm{CDCl}_{3}\right) \delta 7.74(1 \mathrm{H}, \mathrm{d}, J=15.9 \mathrm{~Hz}), 7.73(1 \mathrm{H}, \mathrm{d}, J$ $=15.9 \mathrm{~Hz}), 7.65(1 \mathrm{H}, \mathrm{d}, J=16.1 \mathrm{~Hz}), 7.59-7.53(4 \mathrm{H}, \mathrm{m}), 7.50-7.45$ $(2 \mathrm{H}, \mathrm{m}), 7.44-7.33(9 \mathrm{H}, \mathrm{m}), 6.54(1 \mathrm{H}, \mathrm{d}, J=15.9 \mathrm{~Hz}), 6.51(1 \mathrm{H}, \mathrm{d}$, $J=15.9 \mathrm{~Hz}), 6.37(1 \mathrm{H}, \mathrm{d}, J=16.1 \mathrm{~Hz}), 5.93(1 \mathrm{H}, \mathrm{d}, \mathrm{br}, J=2.4 \mathrm{~Hz})$, $5.60(1 \mathrm{H}, \mathrm{m}, \mathrm{br}), 5.29(1 \mathrm{H}, \mathrm{dt}, \mathrm{br}, J=11.7$ and $3,6 \mathrm{~Hz}), 5.05(1 \mathrm{H}, \mathrm{dd}$, br, $J=10.7$ and $1.7 \mathrm{~Hz}), 3.24(1 \mathrm{H}, \mathrm{t}, \mathrm{br}, J=9.4 \mathrm{~Hz}), 2.53(1 \mathrm{H}, \mathrm{dd}, J=$ 13.2 and $3.9 \mathrm{~Hz}), 2.47(1 \mathrm{H}, \mathrm{m}), 2.27-1.39(19 \mathrm{H}, \mathrm{m}), 1.36(3 \mathrm{H}, \mathrm{s})$, $1.26(3 \mathrm{H}, \mathrm{s}), 1.25(3 \mathrm{H}, \mathrm{s}), 1.11(3 \mathrm{H}, \mathrm{s}, \mathrm{br}), 0.91(3 \mathrm{H}, \mathrm{s}) ;{ }^{13} \mathrm{C}$ NMR $\left(101 \mathrm{MHz}, \mathrm{CDCl}_{3}\right) \delta 202.3,168.3,166.2,166.1,164.9,145.7,145.5$ (2C), 134.3, 134.2 (2C), 130.5 (2C), 130.4, 129.0 (4C), 128.9 (2C), 128.2 (6C), 121.6, 118.0, 117.9, 117.8, 84.5, 80.1, 77.1, 70.7, 69.1, 67.5, 51.2, 49.7, 47.8, 40.3, 38.6, 34.4, 33.7, 31.5, 31.2, 30.3, 29.4, 28.6, 25.0, 23.9, 21.5, 20.6, 20.5, 17.5; (+)-HRESIMS $m / z 893.4229$ $[\mathrm{M}+\mathrm{Na}]^{+}$(calcd for $\mathrm{C}_{54} \mathrm{H}_{62} \mathrm{O}_{10}, 893.4235$ ).

20-Hydroxyecdysone 2,3,22-trioleate (27). This was prepared according to GP-C using 20-hydroxyecdysone (1) and oleyl chloride; FC: $n$-hexane-EtOAc, $1: 1.5$; yield: $56.0 \mathrm{mg}$, $44 \%$; pale yellow thick oil; $[\alpha]^{20}{ }_{\mathrm{D}}+5.88(c \mathrm{1} .08, \mathrm{MeOH}) ;{ }^{1} \mathrm{H} \mathrm{NMR}\left(400 \mathrm{MHz}, \mathrm{CDCl}_{3}\right) \delta$ $5.89(1 \mathrm{H}, \mathrm{d}, \mathrm{br}, J=2.1 \mathrm{~Hz}), 5.44-5.30(7 \mathrm{H}, \mathrm{m}, \mathrm{br}), 5.10(1 \mathrm{H}, \mathrm{dt}, \mathrm{br}, J$ $=12.3$ and $3.4 \mathrm{~Hz}), 4.88(1 \mathrm{H}, \mathrm{d}, \mathrm{br}, J=8.8 \mathrm{~Hz}), 3.15(1 \mathrm{H}, \mathrm{t}, \mathrm{br}, J=$ $8.1 \mathrm{~Hz}), 2.44-2.32(6 \mathrm{H}, \mathrm{m}, \mathrm{br}), 2.24(2 \mathrm{H}, \mathrm{t}, J=7.4 \mathrm{~Hz}), 2.21-1.26$ $(100 \mathrm{H}, \mathrm{m}), 1.25(3 \mathrm{H}, \mathrm{s}), 1.23(3 \mathrm{H}, \mathrm{s}), 1.04(3 \mathrm{H}, \mathrm{s}, \mathrm{br}), 0.89(9 \mathrm{H}, \mathrm{t}, J$ $=7.1 \mathrm{~Hz}), 0.87(3 \mathrm{H}, \mathrm{s}) ;{ }^{13} \mathrm{C} \mathrm{NMR}\left(101 \mathrm{MHz}, \mathrm{CDCl}_{3}\right) \delta 202.7,173.8$, 173.5, 176.0, 165.1, 130.7 (3C), 130.4 (3C), 122.3, 85.2, 80.1, 77.8, $71.3,69.2,67.4,51.7,50.2,48.2,41.0,39.1,35.2,35.1,35.0,34.9$, $34.2,32.3,31.8,30.9,30.5-29.8$ (30C), 30.2, 29.4, 27.9 (6C), 25.8 (3C), 25.4, 24.5, 21.9, 21.2, 21.1, 18.1, 14.8 (3C); (+)-HRESIMS $\mathrm{m} / \mathrm{z}$ $1296.0348[\mathrm{M}+\mathrm{Na}]^{+}$(calcd for $\left.\mathrm{C}_{81} \mathrm{H}_{140} \mathrm{O}_{10}, 1296.0339\right)$.

20-Hydroxyecdysone 2,3,22-tri(2-(1H-indol-3-yl)acetate (28). This was prepared as follows: $N, N^{\prime}$-Dicyclohexylcarbodiimide $(144 \mathrm{mg}, 0.7 \mathrm{mmol})$ was added in portions to a solution of $2-(1 \mathrm{H}-$ indol-3-yl)acetic acid $(123 \mathrm{mg}, 0.7 \mathrm{mmol})$ in dry dioxane $(3 \mathrm{~mL})$ under a nitrogen atmosphere. After $1 \mathrm{~h}$, the white solid was filtered off and the filtrate was added to a suspension of 20-hydroxyecdysone (1) $(48 \mathrm{mg}, 0.1 \mathrm{mmol})$ in dry dioxane $(0.5 \mathrm{~mL})$ and $N, N^{\prime}$ - 
dimethylaminopyridine $(6.0 \mathrm{mg}, 0.05 \mathrm{mmol})$. The reaction mixture was stirred, at $40{ }^{\circ} \mathrm{C}$, for $22 \mathrm{~h}$ under a nitrogen atmosphere and then diluted with EtOAc $(10 \mathrm{~mL})$. The resulting solution was washed with a $5 \%$ aqueous $\mathrm{NaHCO}_{3}, 5 \%$ aqueous $\mathrm{H}_{3} \mathrm{PO}_{4}$, and then brine. The organic phase was dried over $\mathrm{Na}_{2} \mathrm{SO}_{4}$, filtered, and concentrated under reduced pressure to dryness. The resulting crude product was purified by flash column chromatography on $\mathrm{SiO}_{2}$ ( $n$-hexane-EtOAc, $1.5: 1)$; yield: $79.0 \mathrm{mg}, 83 \%$; pale yellow solid; $\mathrm{mp} 157-168{ }^{\circ} \mathrm{C}$; $[\alpha]^{20}{ }_{\mathrm{D}}+26.4(c 1.00, \mathrm{MeOH}) ;{ }^{1} \mathrm{H}$ NMR $\left(400 \mathrm{MHz}, \mathrm{CDCl}_{3}\right) \delta 8.38$ $(2 \mathrm{H}, \mathrm{s}, \mathrm{br}), 8.29(1 \mathrm{H}, \mathrm{s}, \mathrm{br}), 7.65(1 \mathrm{H}, \mathrm{d}, J=7.7 \mathrm{~Hz}), 7.59(1 \mathrm{H}, \mathrm{d}, J=$ $7.8 \mathrm{~Hz}), 7.49(1 \mathrm{H}, \mathrm{d}, J=7.8 \mathrm{~Hz}), 7.36-7.28(3 \mathrm{H}, \mathrm{m}), 7.23-7.09$ $(7 \mathrm{H}, \mathrm{m}), 7.04(1 \mathrm{H}, \mathrm{s}), 6.93(1 \mathrm{H}, \mathrm{s}), 5.73(1 \mathrm{H}, \mathrm{d}, \mathrm{br}, J=1.8 \mathrm{~Hz}), 5.33$ $(1 \mathrm{H}, \mathrm{m}, \mathrm{br}), 5.00(1 \mathrm{H}, \mathrm{d}, \mathrm{br}, J=12.3 \mathrm{~Hz}), 4.80(1 \mathrm{H}, \mathrm{d}, \mathrm{br}, J=10.2$ $\mathrm{Hz}), 3.85(1 \mathrm{H}, \mathrm{d}, J=15.2 \mathrm{~Hz}), 3.81(1 \mathrm{H}, \mathrm{d}, J=15.2 \mathrm{~Hz}), 3.72(1 \mathrm{H}$, d, $J=15.9 \mathrm{~Hz}), 3.69(1 \mathrm{H}, \mathrm{d}, J=15.9 \mathrm{~Hz}), 3.51(2 \mathrm{H}, \mathrm{s}, \mathrm{br}), 3.01(1 \mathrm{H}$, $\mathrm{t}, \mathrm{br}, J=9.1 \mathrm{~Hz}), 2.29-2.21(1 \mathrm{H}, \mathrm{m}), 2.17(1 \mathrm{H}, \mathrm{dd}, J=12.9$ and 3.8 $\mathrm{Hz}), 2.01-1.05(19 \mathrm{H}, \mathrm{m}$, methylene and $\mathrm{OH}$ protons), $1.16(3 \mathrm{H}, \mathrm{s})$, $1.02(3 \mathrm{H}, \mathrm{s}), 0.96(3 \mathrm{H}, \mathrm{s}), 0.83(3 \mathrm{H}, \mathrm{s}), 0.72(3 \mathrm{H}, \mathrm{s}) ;{ }^{13} \mathrm{C} \mathrm{NMR}(101$ $\left.\mathrm{MHz}, \mathrm{CDCl}_{3}\right) \delta 202.9,174.1,172.3,172.2,165.2,136.8,136.7,136.5$, 127.9 (2C), $127.8,124.0,123,8,123.7,123.0,122.8,122.7,122.1$, $120.4,120.3,120.2,119.6,119.5,119.4,112.0-111.9$ (3C), 109.1, $108.9,108.5,84.9,80.7,77.4,71.1,69.9,68.2,51.5,50.1,48.0,40.5$, $38.8,34.4,34.2,32.5,32.0,31.9,31.7$ (2C), 30.4, 29.8, 29.0, 25.4, 24.2, 21.9, 21.1, 21.0, 18.0; (+)-HRESIMS $m / z 974.4558[\mathrm{M}+\mathrm{Na}]^{+}$ (calcd for $\mathrm{C}_{57} \mathrm{H}_{65} \mathrm{~N}_{3} \mathrm{O}_{10}, 974.4562$ ).

Cell Cultures. The CCRF-CEM and LoVo cell lines were purchased from the American Type Culture Collection and were grown in RPMI and Ham's F12, respectively. CEM ${ }^{\mathrm{Vbl} 100}$ and LOVO $^{\text {Doxo }}$ cells in RPMI were a kind gift of Dr. S. Arancia (Istituto Superiore di Sanità, Rome, Italy). CEM ${ }^{\mathrm{Vbl}-100}$ are a multi-drugresistant line selected against vinblastine, ${ }^{35}$ and they grow in RPMI in the presence of $100 \mathrm{ng} / \mathrm{mL}$ vinblastine. $\mathrm{LoVN}^{\text {Doxo }}$ cells are a doxorubicin-resistant subclone of LoVo cells ${ }^{36}$ and were grown in complete Ham's F12 medium supplemented with doxorubicin (100 $\mathrm{ng} / \mathrm{mL}$ ). All media were supplemented with $10 \%$ fetal bovine serum (FBS), glutamine $(2 \mathrm{mM})$, penicillin $(100 \mathrm{U} / \mathrm{mL})$, and streptomycin $(100 \mu \mathrm{g} / \mathrm{mL}$ ) (all from Thermo Fisher Scientific, Waltham, MA, USA).

The medulloblastoma cell line DAOY was purchased from the American Type Culture Collection. Cells were cultured in RPMI 1640 or $\alpha$ MEM (Life Technologies, Italy) supplemented with $10 \%$ FBS, glutamine ( $2 \mathrm{mM}$; Life Technologies, Italy), penicillin $(100 \mathrm{U} / \mathrm{mL}$; Life Technologies, Italy), and streptomycin $(100 \mu \mathrm{g} / \mathrm{mL}$; Life Technologies, Italy) and maintained at $37{ }^{\circ} \mathrm{C}$ in a humidified atmosphere with $5 \% \mathrm{CO}_{2}$.

Evaluation of Cytotoxicity in Peripheral Blood Lymphocytes. Peripheral blood lymphocytes were obtained from human peripheral blood (leucocyte-rich plasma-buffy coats) from healthy donors using Lymphoprep (Fresenius KABI Norge AS) gradient density centrifugation. Buffy coats were collected and provided by the Blood Transfusion Service of Azienda Ospedaliera di Padova only for research purposes, without identifier. The samples were not obtained specifically for this study, and for this reason ethical approval was not required. Informed consent was obtained from blood donors according to Italian law no. 219 (October 21, 2005). Data have been treated by the Blood Transfusion Service according to Italian law on personal management "Codice in materia di protezione dati personali” (Testo Unico D.L. giugno 30, 2003 196). The experimental procedures were carried out in strict accordance with approved guidelines.

After extensive washing, cells were resuspended $\left(1.0 \times 10^{6}\right.$ cells/ $\mathrm{mL}$ ) in RPMI-1640 with 10\% FBS and incubated overnight. For cytotoxicity evaluations in proliferating PBL cultures, nonadherent cells were resuspended at $5 \times 10^{5}$ cells $/ \mathrm{mL}$ in growth medium, containing $2.5 \mu \mathrm{g} / \mathrm{mL}$ PHA (Irvine Scientific). Different concentrations of the test compounds were added, and viability was determined $72 \mathrm{~h}$ later by the MTT test. For cytotoxicity evaluations in resting PBL cultures, nonadherent cells were resuspended $\left(5 \times 10^{5}\right.$ cells $/ \mathrm{mL}$ ) and treated for $72 \mathrm{~h}$ with the test compounds.
Flow Cytometric Analysis of Rhodamine 123. Functional activity of P-glycoprotein was measured with the fluorescent dye Rho123 (Pierce, Rockford IL, USA), which is a substrate of P-gp. Briefly, after different times of treatment, the cells were collected by centrifugation and resuspended in Hank's balanced salt solution (HBSS) containing $0.1 \mu \mathrm{M}$ Rho 123 . The cells were then incubated for $20 \mathrm{~min}$ at $37^{\circ} \mathrm{C}$, centrifuged, and resuspended in HBSS. The fluorescence was directly recorded by flow cytometry with a Coulter Cytomics FC500 (Beckman Coulter).

Flow Cytometric Analysis of Side Population. The protocol of SP analysis was based on Goodell and co-workers. ${ }^{37}$ Briefly, cells $\left(10^{6} / \mathrm{mL}\right)$ were incubated in $\alpha$ MEM containing $2 \%$ FBS (Life Technologies) and $5 \mu \mathrm{g} / \mathrm{mL}$ Hoechst 33342 dye (Sigma-Aldrich) for $90 \mathrm{~min}$ at $37^{\circ} \mathrm{C}$, either alone or in the presence of $50 \mu \mathrm{M}$ verapamil (Sigma). At the end of incubation, cells were washed and then incubated in PBS supplemented with $2 \%$ FCS and $2 \mu \mathrm{g} / \mathrm{mL}$ propidium iodide (Sigma), at $4{ }^{\circ} \mathrm{C}$ for $10 \mathrm{~min}$, to discriminate dead cells. The cells were then analyzed in a MoFlo XDP (Beckman Coulter, USA) equipped with a 355 UV laser to measure both Hoechst blue fluorescence and Hoechst red fluorescence. Based on the Hoechst double emission the SP profile appears as a small fraction of cells forming a tail extending from non-SP populations. A gate on PI-negative cells was used to exclude dead cells, and side population was analyzed on a Hoechst red vs Hoechst blue plot: if present, the SP appears as a dim tail with respect to non-SP. A minimum of 30000 live cells events was acquired.

P-Glycoprotein Activity Assay. P-gp ATPase activity after ecdysteroid treatment was estimated by a P-gp-Glo assay system (Promega, Madison, WI, USA) following the manufacturer's instructions. This method relies on the ATP dependence of the light-generating reaction of firefly luciferase, where ATP consumption is detected as a decrease in luminescence. In a 96-well plate, recombinant human P-gp $(25 \mu \mathrm{g})$ was incubated with P-gp-Glo assay buffer $(20 \mu \mathrm{L})$, verapamil $(200 \mu \mathrm{M})$ as positive control, sodium orthovanadate $(100 \mu \mathrm{M})$ as a P-gp ATPase inhibitor, and the test compounds $(1-10 \mu \mathrm{M})$. The reaction was initiated by addition of MgATP $(10 \mathrm{mM})$, then stopped $40 \mathrm{~min}$ later by addition of $50 \mu \mathrm{L}$ of firefly luciferase reaction mixture (ATP detection reagent), which initiated an ATP-dependent luminescence reaction. Signals were measured $60 \mathrm{~min}$ later by a Victor ${ }^{3 \mathrm{TM}} 1420$ multilabel counter (PerkinElmer, Waltham, MA, USA).

Drug Treatment. Cells were grown to $60 \%$ confluence and then treated with test compounds at a stock concentration of $10 \mathrm{mM}$. Cells were treated for $72 \mathrm{~h}$ using scalar dilutions of P-gp inhibitors 9 and 14, combined with vinblastine, doxorubicin, vincristine at a stock concentration of $10 \mathrm{mM}$, and cisplatin at a stock concentration of 5 $\mathrm{mM}$ (Sigma-Aldrich) and then used at different concentrations. Doxorubicin, vincristine, and cisplatin were added to drug solutions at fixed combination ratios, while vinblastine was added at fixed concentrations of $1 \mu \mathrm{M}$. The effectiveness of various drug combinations was analyzed by the Calcusyn version 2.1 software (Biosoft). The combination index was calculated according to the Chou-Talalay method. ${ }^{19,20}$ A combination index of 1 indicates an additive effect of the two drugs. Combination index values less than 1 indicate synergy, and combination index values more than 1 indicate antagonism.

MTT Assay. Proliferation was assessed by an MTT ((3-(4,5dimethylthiazol-2-yl)-2,5-diphenyl tetrazolium bromide) assay after treatment. Equal concentrations of cells were plated in triplicate in a 96-well plate and incubated with $10 \mu \mathrm{L}$ of MTT (Sigma-Aldrich, St. Louis, MO, USA) for $4 \mathrm{~h}$. Absorbance was measured at $560 \mathrm{~nm}$ using a Victor3 1420 multilabel counter (PerkinElmer). The growth inhibition $\left(\mathrm{GI}_{50}=\right.$ compound concentration required to inhibit cell proliferation by $50 \%$ ) was calculated by plotting the data as a logarithmic function of $(x)$ when viability was $50 \%$. DMSO-treated cell viability was set to $100 \%$. $^{38}$

RNA Isolation and Reverse Transcriptase Polymerase Chain Reaction. Total cellular RNA from cell lines and patient bone marrow was extracted with TRIzol reagent (Invitrogen). RNA quality was controlled using a Nanodrop spectrophotometer. Subsequently, 1 
$\mu \mathrm{g}$ of total RNA was reversely transcribed using random hexamers and Superscript II (Invitrogen), according to the manufacturer's instructions.

Real-Time PCR. Real-time quantitative PCR was performed on an Applied Biosystems 7900 HT sequence detection system using SYBR Green PCR master mixture reagents (Applied Biosystems; Forest City, CA, USA). Primer used for analysis of the ABCB1 gene ( $p$ glycoprotein) F: 5'-CACCAAGGCCCTGCGCTACC-3', R: 5'ACACCCGGTACCCGCGATGA-3' and for the GUS gene F: $5^{\prime}$ GAAAATATGTGGTTGGAGAGC-3'， R: 5' -CGAGTGAAGATCCCCTTTTTA-3'.

Molecular Docking. A homology model of the human Pglycoprotein was built on the crystal structure of mouse Pglycoprotein; PDB code: 3G60. The model was generated with the Yasara software with the default parameters (www.yasara.org). The selected ligands were first submitted to a Monte Carlo conformational search with the MMFF94 force field in vacuo with Spartan '08. ${ }^{39}$ The obtained conformers were used for docking studies. Docking was performed using AutoDock ${ }^{40}$ using the default docking parameters supplied with AutoDock in the "examples" subdirectory, and point charges were initially assigned according to the AMBER03 force field $^{41}$ and then damped to mimic the less polar Gasteiger charges used to optimize the AutoDock scoring function. The setup was done with the YASARA molecular modeling program. ${ }^{42}$ For each ligand 75 Autodock LGA runs were executed. Results were sorted by binding energy (more positive energies indicate stronger binding, and negative energies mean no binding). After clustering the 75 runs, the resulting complex conformations were originated and clustered (they all differed by at least 5.0 A heavy atom RMSD). Binding energies are reported in $\mathrm{kcal} / \mathrm{mol}$, and predicted dissociation constants in $\mathrm{pM}$ units. Contacting receptor residues are also listed. After the clustering the energy spread [average and standard deviation] was calculated: the dissociation constant has been recalculated from the average binding energy. ${ }^{43}$

Statistical Analysis. All experiments were performed with a minimum of three technical and three biological replicates, and values reported are the mean of the three biological replicates, unless otherwise indicated. Error bars represent the standard error of the mean (SEM), unless otherwise indicated. All statistical analyses were performed using the GraphPad Prism software (version 7.0).

\section{ASSOCIATED CONTENT}

\section{(s) Supporting Information}

The Supporting Information is available free of charge at https://pubs.acs.org/doi/10.1021/acs.jnatprod.0c00334.

${ }^{1} \mathrm{H}$ NMR and ${ }^{13} \mathrm{C}$ NMR spectra of all synthesized compounds (PDF)

\section{AUTHOR INFORMATION}

\section{Corresponding Authors}

Roberta Bortolozzi - Dipartimento di Salute della Donna e del Bambino, Laboratorio di Oncoematologia, Università degli Studi di Padova, Padova 35128, Italy; Istituto di Ricerca Pediatrica (IRP), Padova 35129, Italy; 이이.org/00000002-3357-4815; Phone: +39049 8215485;

Email: roberta.bortolozzi@unipd.it

Alessandra Silvani - Dipartimento di Chimica, Università di Milano, Milano 20133, Italy; 잉o․org/0000-0002-03972636; Phone: +39 2 50314080; Email: alessandra.silvani@ unimi.it

\section{Authors}

Andrea Luraghi - Dipartimento di Chimica, Università di Milano, Milano 20133, Italy
Elena Mattiuzzo - Dipartimento di Salute della Donna e del Bambino, Laboratorio di Oncoematologia, Università degli Studi di Padova, Padova 35128, Italy

Alessandro Sacchetti - Dipartimento di Chimica, Materiali ed Ingegneria Chimica "Giulio Natta", Politecnico di Milano, Milano 20133, Italy; (1) orcid.org/0000-0002-4830-0825

Giampietro Viola - Dipartimento di Salute della Donna e del Bambino, Laboratorio di Oncoematologia, Università degli Studi di Padova, Padova 35128, Italy; Istituto di Ricerca Pediatrica (IRP), Padova 35129, Italy

Complete contact information is available at:

https://pubs.acs.org/10.1021/acs.jnatprod.0c00334

\section{Author Contributions}

$\triangle_{\mathrm{R}}$. Bortolozzi and A. Luraghi contributed equally to this work.

Notes

The authors declare no competing financial interest.

\section{REFERENCES}

(1) Bukowski, K.; Kciuk, M.; Kontek, R. Int. J. Mol. Sci. 2020, 21, E3233.

(2) Fletcher, J. I.; Haber, M.; Henderson, M. J.; Norris, M. D. Nat. Rev. Cancer 2010, 10, 147-156.

(3) Amawi, H.; Sim, H. M.; Tiwari, A. K.; Ambudkar, S. V.; Shukla, S. Adv. Exp. Med. Biol. 2019, 1141, 549-580.

(4) Binkhathlan, Z.; Lavasanifar, A. Curr. Cancer Drug Targets 2013, $13,326-346$

(5) Alexa-Stratulat, T.; Pešić, M.; Gašparović, A. Č.; Trougakos, I. P.; Riganti, C. Drug Resist. Updates 2019, 46, 100643.

(6) Falasca, M.; Linton, K. J. Expert Opin. Invest. Drugs 2012, 21, 657-666.

(7) Kumar, V.; Kumar, V.; McGuire, T.; Coulter, D. W.; Sharp, J. G.; Mahato, R. I. Trends Pharmacol. Sci. 2017, 38, 1061-1084.

(8) Othman, R. T.; Kimishi, I.; Bradshaw, T. D.; Storer, L. C.; Korshunov, A.; Pfister, S. M.; Grundy, R. G.; Kerr, I. D.; Coyle, B. Acta Neuropathol. Commun. 2014, $2,57$.

(9) Dinan, L.; Lafont, R. J. J. Endocrinol. 2006, 191, 1-8.

(10) Dinan, L.; Savchenko, T.; Whiting, P. Cell. Mol. Life Sci. 2001, $58,1121-1132$.

(11) Lafont, R.; Dinan, L. J. Insect Sci. 2003, 3, 7.

(12) Báthori, M.; Tóth, N.; Hunyadi, A.; Márki, Á. E.; Zádor, E. Curr. Med. Chem. 2008, 15, 75-91.

(13) Martins, A.; Tóth, N.; Ványolós, A.; Béni, Z.; Zupkó, I.; Molnár, J.; Báthori, M.; Hunyadi, A. J. J. Med. Chem. 2012, 55, 50345043.

(14) Martins, A.; Sipos, P.; Dér, K.; Csábi, J.; Miklos, W.; Berger, W.; Zalatnai, A.; Amaral, L.; Molnár, J.; Szabó-Révész, P.; Hunyadi, A. BioMed Res. Int. 2015, 2015, 895360.

(15) Lesma, G.; Luraghi, A.; Rainoldi, G.; Mattiuzzo, E.; Bortolozzi, R.; Viola, G.; Silvani, A. Synthesis 2016, 48, 3907-3916.

(16) Fumagalli, G.; Giorgi, G.; Vágvölgyi, M.; Colombo, E.; Christodoulou, M. S.; Collico, V.; Prosperi, D.; Dosio, F.; Hunyadi, A.; Montopoli, M.; Hyeraci, M.; Silvani, A.; Lesma, G.; Via, L. D.; Passarella, D. ACS Med. Chem. Lett. 2018, 9, 468-471.

(17) Petriz, J.; Garcia Lopez, J. Leukemia 1997, 11, 1124-1130.

(18) Ferreira, R. J.; Ferreira, M. J. U.; Dos Santos, D. J. V. A. J. Chem. Inf. Model. 2013, 53, 1747-1760.

(19) Chou, T. C. Pharmacol. Rev. 2006, 58, 621-681.

(20) Chou, T. C. Cancer Res. 2010, 70, 440-446.

(21) Muller, C.; Bailly, J. D.; Goubin, F.; Laredo, J.; Jaffrézou, J. P.; Bordier, C.; Laurent, G. Int. J. Cancer 1994, 56, 749-754.

(22) Dean, M.; Fojo, T.; Bates, S. Nat. Rev. Cancer 2005, 5, 275284. 
(23) Bleau, A. M.; Hambardzumyan, D.; Ozawa, T.; Fomchenko, E. I.; Huse, J. T.; Brennan, C. W.; Holland, E. C. Cell Stem Cell. 2009, 4, $226-235$.

(24) Hirschmann-Jax, C.; Foster, A. E.; Wulf, G. G.; Nuchtern, J. G.; Jax, T. W.; Gobel, U.; Goodell, M. A.; Brenner, M. K. Proc. Natl. Acad. Sci. U. S. A. 2004, 101, 14228-14233.

(25) Geng, S. Q.; Alexandrou, A. T.; Li, J. J. Cancer Lett. 2014, 349, $1-7$.

(26) MacDonagh, L.; Gray, S. G.; Breen, E.; Cuffe, S.; Finn, S. P.; O’Byrne, K. J.; Barr, M. P. Cancer Lett. 2016, 372, 147-56.

(27) Skvortsov, S.; Skvortsova, I. I.; Tang, D. G.; Dubrovska, A. Stem Cells 2018, 36, 1457-1474.

(28) Hatina, J.; Boesch, M.; Sopper, S.; Kripnerova, M.; Wolf, D.; Reimer, D.; Marth, C.; Zeimet, A. G. Adv. Exp. Med. Biol. 2019, 1139, 201-221.

(29) Persano, L.; Rampazzo, E.; Basso, G.; Viola, G. Biochem. Pharmacol. 2013, 85, 612-622.

(30) Amsterdam, A.; Raanan, C.; Schreiber, L.; Polin, N.; Givol, D. Biochem. Biophys. Res. Commun. 2013, 433, 157-62.

(31) Nassar, D.; Blanpain, C. Annu. Rev. Pathol.: Mech. Dis. 2016, 11, $47-76$.

(32) Szewczyk, P.; Tao, H.; McGrath, A. P.; Villaluz, M.; Rees, S. D.; Lee, S. C.; Doshi, R.; Urbatsch, I. L.; Zhang, Q.; Chang, G. Acta Crystallogr., Sect. D: Biol. Crystallogr. 2015, 71, 732-741.

(33) Aller, S. G.; Yu, J.; Ward, A.; Weng, Y.; Chittaboina, S.; Zhuo, R.; Harrell, P. M.; Trinh, Y. T.; Zhang, Q.; Urbatsch, I. L.; Chang, G. Science 2009, 323, 1718-1722.

(34) Zeino, M.; Paulsen, M. S.; Zehl, M.; Urban, E.; Kopp, B.; Efferth, T. Biochem. Pharmacol. 2015, 93, 11-24.

(35) Toffoli, G.; Viel, A.; Tumiotto, I.; Biscontin, G.; Rossi, G.; Baiocchi, M. Br. J. Cancer 1991, 63, 51-56.

(36) Dupuis, M. L.; Flego, M.; Molinari, A.; Cianfriglia, M. HIV Med. 2003, 4, 338-345.

(37) Goodell, M. A.; Brose, K.; Paradis, G.; Conner, A. S.; Mulligan, R. C. J. J. Exp. Med. 1996, 183, 1797-1806.

(38) Romagnoli, R.; Baraldi, P. G.; Lopez-Cara, L. C.; Kimatrai Salvador, M.; Preti, D.; Aghazadeh Tabrizi, M.; Balzarini, J.; Nussbaumer, P.; Brancale, A.; Fu, X.; Li, J.; Zhang, S.; Hamel, E.; Bortolozzi, R.; Basso, G.; Viola, G. Bioorg. Med. Chem. 2014, 22, 5097-5109.

(39) Spartan'08; Wavefunction, Inc.: Irvine, CA, 2008.

(40) Morris, G. M.; Huey, R.; Lindstrom, W.; Sanner, M. F.; Belew, R. K.; Goodsell, D. S.; Olson, A. J. J. J. Comput. Chem. 2009, 209, 2785-2791.

(41) Duan, Y.; Wu, C.; Chowdhury, S.; Lee, M. C.; Xiong, G.; Zhang, W.; Yang, R.; Cieplak, P.; Luo, R.; Lee, T. J. J. Comput. Chem. 2003, 24, 1999-2012.

(42) Krieger, E.; Vriend, G. Bioinformatics 2014, 30, 2981-2982.

(43) Krieger, E.; Darden, T.; Nabuurs, S.; Finkelstein, A.; Vriend, G. Proteins: Struct., Funct., Genet. 2004, 57, 678-683. 